\title{
A Critical Appraisal of the Role of Clay Mineralogy in Lime Stabilization
}

\author{
C. Cherian · D. N. Arnepalli
}

Received: 8 December 2014/ Accepted: 3 January 2015/Published online: 21 January 2015

(c) Springer International Publishing AG 2015

\begin{abstract}
The stabilization of problematic fine-grained soils using lime as an admixture is a widely accepted practice, owing to its simplicity and cost-effectiveness. The optimal quantity of lime required for soil stabilization primarily depends upon the reactive nature of soil as well as the degree of improvement desired. The term 'optimum lime content' (OLC) defines the amount of lime required for satisfying the immediate/short-term soil-lime interaction, and still providing sufficient amount of free calcium and high residual $\mathrm{pH}$ necessary to initiate long-term pozzolanic reaction. Previous researchers proposed various empirical correlations and experimental methodologies for determining OLC, in terms of clay-size fraction and plasticity characteristics of virgin soil. However, the limiting lime content obtained using various conventional methods does not account for the most influencing inherent clay mineralogy of the soil; and hence, the results of these methodologies are observed to be quite disagreeing with each other. In view of these discrepancies, the present study attempts to validate the existing conventional methodologies for OLC determination at an elementary level, by comprehending the fundamental chemistry following soil-lime interactions. Based on the theoretical and experimental observations, it is quite evident that the accuracy of conventional tests is limited by combined influence of chemical and mineralogical properties of soils. Hence, it is proposed to develop a precise methodology to ascertain the required optimal lime dosage based on
\end{abstract}

C. Cherian · D. N. Arnepalli $(\bowtie)$

Department of Civil Engineering, Indian Institute of Technology

Madras, Chennai 600036, India

e-mail: arnepalli@iitm.ac.in

C. Cherian

e-mail: chinchu0401@gmail.com scientific criteria, by incorporating the influence of soil properties such as clay mineralogy, specific surface area, soil $\mathrm{pH}$, cation exchange capacity, soil acidity, base saturation capacity, and buffer capacity.

Keywords Stabilization - Pozzolanic reaction - Optimum lime content - Soil pH - Cation exchange capacity .

Base saturation capacity · Buffer capacity

$\begin{array}{ll}\text { List of Symbols } & \\ 1 / k & \text { Thickness of diffused double layer } \\ \mathrm{BpH} & \text { Buffer pH } \\ \mathrm{BSC} & \text { Base saturation capacity } \\ \mathrm{BSC}_{[\mathrm{K}]} & \text { Base saturation capacity pertinent to } \\ & \mathrm{K}^{+} \\ \mathrm{BSC}_{[\mathrm{Mg}]} & \text { Base saturation capacity pertinent to } \\ & \mathrm{Mg}^{2+} \\ \mathrm{BSC}_{[\mathrm{Na}]} & \mathrm{Base} \\ & \mathrm{Na}^{+} \\ \mathrm{C}-\mathrm{A}-\mathrm{H} & \mathrm{Calcium}^{+} \\ \mathrm{C}-\mathrm{A}-\mathrm{S}-\mathrm{H} & \text { Calcium aluminate hydrate } \\ \mathrm{CBR} & \text { California bearing ratio } \\ \mathrm{CEC} & \text { Cation exchange capacity } \\ \mathrm{CEC} & \text { Cation exchange capacity pertinent } \\ \mathrm{CH} & \text { to Ca } \\ \mathrm{CI} & \text { Clay of high plasticity } \\ \mathrm{CPS} & \text { Clay of intermediate plasticity } \\ \mathrm{C}-\mathrm{S}-\mathrm{H} & \text { Counts per second } \\ & \text { Calcium silicate hydrate or calcium } \\ \mathrm{DDL} & \text { silicate hydrogel } \\ \mathrm{DT} & \text { Diffused double layer } \\ e & \text { Dwell time } \\ \mathrm{EC} & \text { Electron charge } \\ E D S & \text { Electrical conductivity } \\ & \text { Energy dispersive spectrometry }\end{array}$




\begin{tabular}{|c|c|}
\hline EGME & Ethylene glycol monoethyl ether \\
\hline EM & $\begin{array}{l}\text { Electrophoretic mobility at specified } \\
\text { temperature }\end{array}$ \\
\hline G & Specific gravity \\
\hline ICDD & $\begin{array}{l}\text { International Centre for Diffraction } \\
\text { Data }\end{array}$ \\
\hline ICL & Initial consumption of lime \\
\hline K & Boltzmann constant \\
\hline$K T$ & Kaolinite \\
\hline$L_{\mathrm{m}}$ & Lime fixation point \\
\hline LS & Live seconds \\
\hline NBT & Sodium bentonite \\
\hline OLC & Optimum lime content \\
\hline $\mathrm{pH}_{\mathrm{pzc}}$ & $\begin{array}{l}\mathrm{pH} \text { value corresponding to point of } \\
\text { zero charge }\end{array}$ \\
\hline pzc & Point of zero charge \\
\hline$S C$ & Sandy clay \\
\hline SEM & Scanning electron microscope \\
\hline SSA & Specific surface area \\
\hline $\mathrm{SSA}_{\mathrm{KT}}$ & Specific surface area of kaolinite \\
\hline $\mathrm{SSA}_{\mathrm{NBT}}$ & $\begin{array}{l}\text { Specific surface area of sodium } \\
\text { bentonite }\end{array}$ \\
\hline $\mathrm{SSA}_{\mathrm{SC}}$ & Specific surface area of sandy clay \\
\hline$T$ & Absolute temperature \\
\hline TBSC & Total base saturation capacity \\
\hline $\mathrm{TBSC}_{[\mathrm{Na}, \mathrm{K}, \mathrm{Ca}, \mathrm{Mg}]}$ & $\begin{array}{l}\text { Total base saturation capacity } \\
\text { pertinent to } \mathrm{Na}^{+}, \mathrm{K}^{+}, \mathrm{Ca}^{2+} \text { and } \\
\mathrm{Mg}^{2+}\end{array}$ \\
\hline TEM & Transmission electron microscope \\
\hline$V_{\mathrm{t}}$ & Viscosity of suspending liquid \\
\hline XRD & $\mathrm{X}$-ray diffraction \\
\hline XRF & $\mathrm{X}$-ray fluorescence \\
\hline $\mathrm{ZP}$ & Zeta potential \\
\hline$\varepsilon$ & Dielectric constant of water \\
\hline$\varepsilon_{0}$ & Dielectric permittivity of vacuum \\
\hline$\varepsilon_{\mathrm{t}}$ & Dielectric constant \\
\hline$\zeta$ & Zeta potential \\
\hline$\eta_{0}$ & Ion concentration \\
\hline & Cation valence \\
\hline
\end{tabular}

\section{Introduction}

Before the discovery of Portland cement, the most effective and most popular cementitious material known to man was lime. This fact is evident from the widespread distribution of lime-based mortars and concrete found in ancient structures. It is not possible to pinpoint the earliest users of lime in construction; however, it can be presumed that the ancient Greeks, Romans, Persians, Indians, Egyptians and Chinese were familiar with the usage of lime for construction purposes [1]. In addition to its role as a construction material, lime in the form of quick- and hydratedlime is also used as an admixture for soil stabilization, in order to enhance the workability, strength, stiffness and durability of majority of fine-grained soils. The history of lime stabilized soil in the current century can probably be divided into two stages; i.e., before and after the Second World War [1]. Before the war, use of lime in arid and semiarid regions of developing nations was popular owing to ease of application and relatively low cost. Post-war, with the progress in modern technology and development of sophisticated analytical and laboratory methods, more comprehensive information related to soil-lime-water system was revealed; as a result, production of lime increased dramatically. In the present days, use of lime in many tropical countries is very popular owing to greater effectiveness of soil-lime reaction at moderate temperatures [1].

When hydrated-lime $\left(\mathrm{Ca}[\mathrm{OH}]_{2}\right)$ is mixed with soil in the presence of adequate moisture content, the divalent calcium $\left(\mathrm{Ca}^{2+}\right)$ ions and monovalent hydroxyl $\left(\mathrm{OH}^{-}\right)$ions will dissociate into pore solution, and consequently increase the soil solution $\mathrm{pH}$. It favors the exchange of $\mathrm{Ca}^{2+}$ cations from lime with the monovalent cations (viz., $\mathrm{Na}^{+}, \mathrm{K}^{+}$, etc.) present in the diffused double layer (DDL) of negatively charged soil minerals [2]. The increased $\mathrm{Ca}^{2+}$ concentration in pore solution also causes reduction of DDL thickness and flocculationagglomeration of clay particles [3]. As a result, the plasticity index drops instantaneously with improved workability and immediate strength enhancement [4], and the whole process is referred to as short-term modification. Simultaneously, the $\mathrm{pH}$ of soil-lime mixture is progressively increased to 12.4 (approximately equal to that of saturated lime solution) by the dissolution of $\mathrm{OH}^{-}$ions from lime [5]. The highly alkaline $\mathrm{pH}$ condition induces dissolution of reactive silica $\left(\mathrm{Si}^{4+}\right)$ and alumina $\left(\mathrm{Al}^{3+}\right)$ ions present in the soil minerals within the medium [6]. Following, the pozzolanic reactions occur between free $\mathrm{Ca}^{2+}$ ions from lime and dissolved $\mathrm{Si}^{4+}$ and $\mathrm{Al}^{3+}$ ions from soil, forming calcium-silicates and aluminates, which later transforms into hydrates and form cementitious compounds (viz., C-S-H, C-A-H and $\mathrm{C}-\mathrm{A}-\mathrm{S}-\mathrm{H}$ ) in the presence of adequate moisture [7]. The pozzolanic reactions might extend to prolonged duration depending on the nature and availability of reactive clay minerals in the soil, and eventually lead to progressive development of strength, stiffness and durability of the stabilized soil [8]. This phenomenon is termed as long-term stabilization, and is affected by the clay mineralogy, compaction state of soil-lime mix, as well as curing conditions [7].

The amount of lime required for modification and stabilization of in situ soil (termed as optimum lime content, OLC) depends primarily on various factors such as extent of improvement desired, type of soil and clay content, type of lime, prevailing environmental conditions, etc. [6]. In 
the past, several studies have been conducted in this realm, and pioneers have developed different empirical formulations and experimental methodologies to determine the optimal lime requirement [9-13]. However, it is apparent from the previous studies that the phenomenon of claylime interaction is very complex and not fully understood, and that the reaction products which form during the longterm stabilization process are not completely characterized. The critical review of the literature suggests that not many efforts have been made to fundamentally comprehend and significantly quantify the potential influence of mineralogical properties and reactive nature of soil on the optimum lime requirement. Hence, it is believed that an elementary and molecular level study of pozzolanic reaction mechanism is indispensible for justifying the macro-scale changes, in terms of physical and geotechnical properties, occurring in lime-treated soils.

In view of this, the manuscript showcases the critical appraisal of the conventional methodologies that are popularly employed for determining the OLC in terms of their basic principles, functional suitability and major limitations. Moreover, the study attempts to comprehend the fundamental reaction mechanisms involved in the existing methodologies for OLC determination, by precisely estimating the influence of most prominent chemical and mineralogical characteristics of virgin soil upon OLC value [viz., origin and geology, soil $\mathrm{pH}$, specific surface area (SSA) and charge density, cation exchange capacity (CEC), zeta potential (ZP), soil acidity, base saturation capacity (BSC), and buffer capacity]. The study has been conducted in two stages, primary being the theoretical evaluation of influence of clay mineralogy on the soil-lime interactions. The secondary stage involves the experimental investigations carried out for soil characterization and quantification of OLC value using conventional tests, followed by the critical evaluation of inherent limitations of conventional tests owing to influence of various chemicomineralogical properties of soils.

\section{Optimum Lime Content and Influencing Factors}

When lime is added to fine-grained soil for improvement of its physico-mechanical properties, initially all the available calcium $\left(\mathrm{Ca}^{2+}\right)$ ions are adsorbed onto inter- and intralayer surface of clay minerals present in the soil in order to satisfy the affinity owing to charge deficiency. This phenomenon is termed as lime fixation, and the amount of lime fixed in the soil is referred to as lime fixation point $\left(L_{\mathrm{m}}\right)$ or initial consumption of lime, ICL [9]. Accordingly, Hilt and Davidson [9] developed a mathematical correlation between $L_{\mathrm{m}}$ and clay-size fraction, i.e., $\leq 2 \mu \mathrm{m}$, which is represented in the form of Eq. 1.
$L_{\mathrm{m}}=\frac{\text { Clay size fraction }(\%)}{35}+1.25$.

According to Bell [6], a lime content of $1-3 \%$ by weight of the soil can completely satisfy the affinity for inter-lamellar calcium exchange, and bring about maximum modification of soil properties. This nominal quantity of lime poses significant changes in the plasticity characteristics of the soil, by altering the charge distribution on the clay surface; and hence, the thickness of DDL [14]. Subsequently, the clay platelets undergo flocculation leading to increase in soil aggregate size; and, thereby cause improvement in workability and short-term strength as well. Nevertheless, ICL do not contribute to long-term strength development, since free calcium ions are not available to take part in the pozzolanic reaction that follows. Based on this, Nelson and Miller [12] developed a methodology to determine ICL in terms of liquid limit and plasticity index, as the minimum percentage of lime required to modify the plasticity characteristics of a soil. Any further addition of lime beyond ICL becomes excess, and it takes part in the chemical and pozzolanic reactions to enhance permanent strength and stiffness properties [15]. The chemical and pozzolanic reactions can continue as far as sufficient reactive clay minerals, free calcium ions and adequate moisture are available in the soil-lime mixture; and therefore, all reactions will cease when no more dissolved silica-alumina and free calcium ions exist in the soil-lime system. Beyond this stage, the excess free-lime existing in the soil-lime matrix precipitates in the voids of aggregates and causes loss of inter-particle friction. Another detrimental/deleterious effect can be the lime carbonation, as a result of which either strength continues to increase at a reduced rate and/or eventually begins to decline [15]. Moreover, studies infer that calcium-based stabilizers such as lime and class-C fly ash are not suitable for effective stabilization of sulphate-rich soils, owing to ettringite-based sulphate-induced heave damages in treated soils [16].

The concept of OLC in the area of lime stabilization was introduced by Eades and Grim [10], which is defined as the amount of lime which can provide sufficient amount of free calcium required for short-term improvement of soil in terms of its workability and plasticity, as well as long-term enhancement of its strength, stiffness and durability [17]. Eades and Grim [10] suggested a methodology to determine OLC of a particular soil type as the lowest percentage of lime required to maintain a soil-lime-water solution $\mathrm{pH}$ of 12.4 (which is equivalent to $\mathrm{pH}$ of a saturated lime solution), and this method was later modified into American Society of Testing Materials (ASTM) standard for determining the optimal lime content [13]. The lime retention point is another term commonly referred by the 
researchers as the quantity of lime which must be maintained in the soil-lime-water system to ensure complete dissolution of reactive silica and alumina from clay minerals [10]. Clara and Handy [18] observed that the viscosity of lime-soil slurry and floc size reach maxima at lime retention point. Ingles and Metcalf [11] suggested a thumb rule of adding $1 \%$ by weight of lime for every $10 \%$ of clay-size fraction present in the soil, for its in situ stabilization. The author also commented that it is quite exceptional for any in situ soil to exhibit clay-size contents above $80 \%$; and hence, the OLC value will be well below $8 \%$. Basma and Tuncer [19] suggested that OLC will be always higher than ICL, usually $2-8 \%$ by weight of dry soil.

\section{Factors Influencing Optimum Lime Content}

There are various influential factors which are presumed to impart significant effect in determining the OLC value and consequent strength and stiffness development. Though, from the various conclusive studies reported in literature it is inferred that the manner in which lime interacts with clay minerals is multifarious. Most of the scientific research works and field projects employed conventional methods such as Eades and Grim test [10] for determining OLC without considering the inherent limitations of these tests. In this context, the following section discusses the major chemico-mineralogical properties of virgin soil which governs the extent of lime reactivity; and hence, the OLC value, namely (a) origin and geology, (b) soil $\mathrm{pH}$, (c) SSA and charge density, (d) ZP, (e) CEC, (f) soil acidity, (g) BSC, and (h) buffer capacity.

\section{Origin and Geology}

The clay minerals present in various natural soils are secondary minerals formed by chemical weathering processes, which include continual loss of major alkali and alkaline earth elements such as calcium, magnesium, potassium, sodium, etc., from the parent material [20]. Among these, calcium is the most abundant cation followed by magnesium, and the soils containing these cations are probably neutral and alkaline, respectively [21]. Heavily weathered soils have net negative surface charges; and therefore, the pore solution has excess of anions. Further, they have generally low $\mathrm{pH}$ (neutral to acidic) compared to poorly weathered soils (which are mostly alkaline) due to the presence of organic matter in the latter [20]. The 1:1 layered structure of kaolinite $(K T)$ is formed by chemical weathering and disintegration of aluminium rich feldspar and mica particles or other acidic igneous rocks, followed by precipitation from $\mathrm{Al}[\mathrm{OH}]_{3}$ and $\mathrm{Si}[\mathrm{OH}]_{4}$ in pore solution. The generic chemical formula for $K T$ group of clay minerals is $\mathrm{Al}_{4} \mathrm{Si}_{4} \mathrm{O}_{10}[\mathrm{OH}]_{8} \cdot n \mathrm{H}_{2} \mathrm{O}$, and Fig. 1 represents

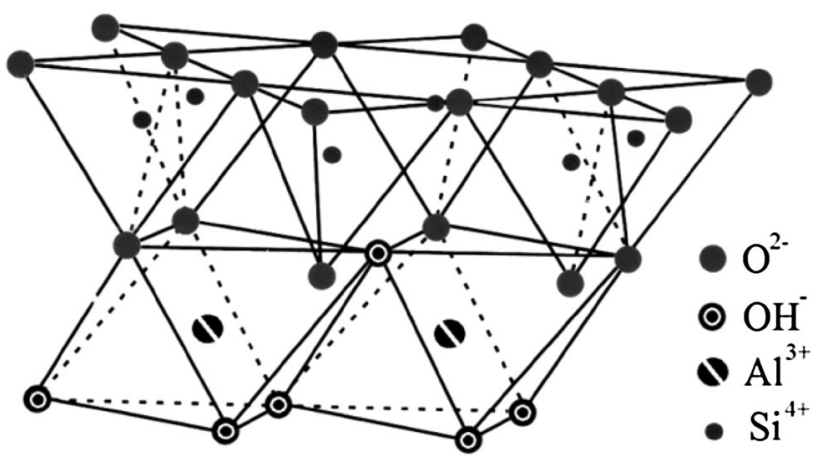

Fig. 1 Schematic of 1:1 type (kaolinite) layered arrangement of clay mineral [22]

the 1:1 type layered structure having one tetrahedral silica sheet linked with one octahedral alumina sheet $[21,22]$. When the layers are stacked one above the other, $\mathrm{O}^{2-}$ of silica sheet and $\mathrm{OH}^{-}$of alumina sheet forms very strong hydrogen bond; and hence, $K T$ minerals are characterized by insignificant expansive nature. Equation 2 presents the hydrolysis reaction leading to its genesis during weathering process. The $\mathrm{Al}^{3+}$ cations accumulate and remain as residual deposits in clay mineral fraction in the form of insoluble aluminium-silicates and hydroxy-oxides, when $\mathrm{SiO}_{2}$ and $\mathrm{KOH}$ leach away by long-term weathering process $[20,23]$.

$\begin{aligned} 4 \mathrm{KAlSi}_{3} \mathrm{O}_{8}+6 \mathrm{H}_{2} \mathrm{O}= & \mathrm{Al}_{4} \mathrm{Si}_{4} \mathrm{O}_{10}(\mathrm{OH})_{8}+8 \mathrm{SiO}_{2} \\ & +4 \mathrm{KOH} .\end{aligned}$

The bentonite is composed of clay mineral smectites, mainly montmorillonite which is formed by chemical weathering/hydrothermal alteration of extrusive basaltic rocks such as tuffs, volcanic ash, etc. [24]. They have 2:1 type layered structure with one alumina octahedral sheet sandwiched between silica tetrahedral sheets (as depicted in Fig. 2), and the generic chemical formula is given by $[0.5 \mathrm{Ca}$, $\mathrm{Na}][\mathrm{Al}, \mathrm{Mg}, \mathrm{Fe}]_{4}[\mathrm{Si}, \mathrm{Al}]_{8} \mathrm{O}_{20}[\mathrm{OH}]_{4} \cdot n \mathrm{H}_{2} \mathrm{O}[22,24]$. The aluminium ion in one-eighth of the octahedral sheet will be replaced by magnesium ion thereby developing a surface negative charge [25]. In case of sodium bentonite (NBT), these negative charges are neutralized by hydrated sodium ions adsorbed to surface of the sheets; and hence, it is named after the dominating exchangeable cation present in it. Moreover, the adjacent sheets of bentonite are linked by weaker van der Waals bonding between $\mathrm{O}^{2-}$ ions; and hence, they are characterized by very high expansive nature.

The wide range of structural compositions and associated morphological properties such as layer thickness, composition (whether tetrahedral or octahedral, and the ionic content) as well as the stacking order of layers and degree of order, predominantly influence the chemicomineralogical properties such as CEC, SSA, BSC, buffer capacity, etc. [26]. Consequently, the soils containing 


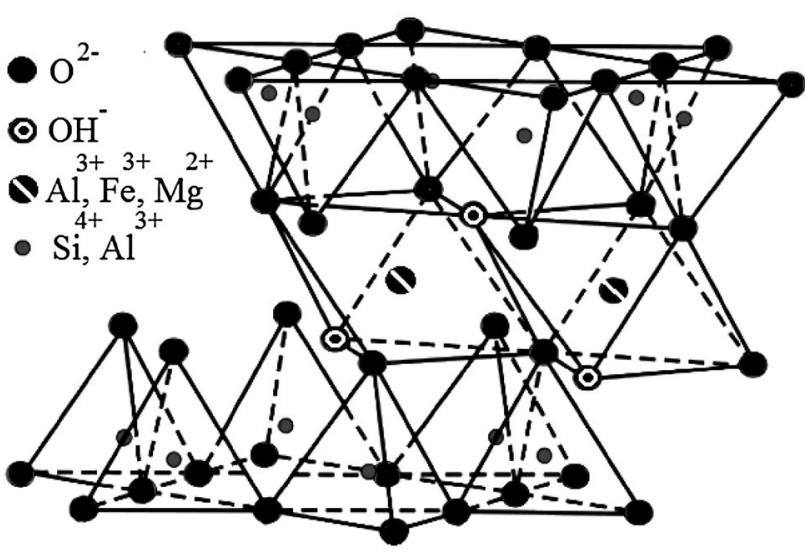

Fig. 2 Schematic of 2:1 type (bentonite) layered arrangement of clay mineral [22]

different clay minerals are also characterized by different rates of chemical reactivity with lime during the short- and long-term stabilization processes. As discussed above, the strong hydrogen bonding, low $\mathrm{pH}$ and deficiency of interand intra-layer spaces in $K T$ mineral reduces its capacity to supply reactive silica and alumina, and consequently leads to poorer lime reactivity. Whereas, $N B T$ which exhibits relatively higher rate of lime reactivity owing to its weaker van der Waals bonding, high alkaline $\mathrm{pH}$ as well as availability of larger inter- and intra-layer spaces can supply more reactive silica and alumina. Therefore, during lime stabilization bentonite requires more amount of lime; and hence, higher OLC value compared to $K T$, in order to satisfy the short-term affinity for charge deficiency and attain satisfactory degree of long-term improvement.

\section{Soil $p H$}

Soil $\mathrm{pH}$ is the measure of acidity or alkalinity of the soil solution; hence, also referred as "soil-water" $\mathrm{pH}$ [27]. The $\mathrm{pH}$ characterizes the physicochemical environment of soil at a given site, this being the result of instantaneous equilibrium controlled by different components of the medium such as organic matter, salt precipitation from strong acids and bases, contamination by oil spills, etc. [28]. The soil $\mathrm{pH}$ is generally reported as a value between 0 and 14; $\mathrm{pH} 7$ is considered as neutral and $\mathrm{pH}$ below and above 7 is acidic and alkaline, respectively. The $\mathrm{pH}$ has a logarithmic scale in which each whole number corresponds to a factor of 10 . For example, if the $\mathrm{pH}$ of soil lowers or rises by one unit, there is 10 -folds increase in the acidity or alkalinity, respectively. Therefore, it can be inferred that even the slightest change in soil $\mathrm{pH}$ have significant effects on soil properties. When soil is mixed with water/solute, the net negative charge of clay particles extend electrically out into the pore solution, and is balanced by excess cations in it [20]. Moreover, most of the soil reactions occur at soil solution/interface, since the ions can move faster enough for easy measurement [20].

The soil $\mathrm{pH}$ depends primarily on two major factors, liquid-solid ratio and ion concentration in the pore fluid. Increasing either of these parameters will decrease solution $\mathrm{pH}$, because $\mathrm{H}^{+}$and $\mathrm{Al}^{3+}$ acid cations present on or near the soil surface can be replaced by other cations in solution. This is supported by the fact that higher concentration of one ionic species relative to other can supersede the effect of charge and hydrated radius [29, 30]. Generally, kaolinitic soils exhibit relatively low $\mathrm{pH}$ value ranging from 3 to 6 , whereas illitic and montmorillonitic soils are characterized by alkaline $\mathrm{pH}$ in the range of 8 to 12 . The acidic nature of $K T$ clay minerals might be attributed to the chemical interaction between water molecules present in DDL and exchangeable $\mathrm{Al}^{3+}$ cations which are strongly held on the surface of clay platelets. The vigorous aluminium-water reaction repels $\mathrm{H}^{+}$ions from water molecules into pore solution; and thereby, $\mathrm{pH}$ of solution drops to acidic range [26]. At the same time, during the interaction between $N B T$ and water, the exchangeable $\mathrm{Na}^{+}$ cations which are weakly adsorbed on clay surface by van der Waals forces will be replaced by strongly adsorbed $\mathrm{H}^{+}$ ions and leave $\mathrm{OH}^{-}$ions in solution; and hence, $\mathrm{pH}$ raise to alkaline range [26]. The generic chemical reactions associated with $K T$ and $N B T$ clay minerals in the presence of water are presented in Eqs. 3 and 4, respectively.

Soil-Al ${ }^{3+}+\mathrm{H}_{2} \mathrm{O}=$ Soil- $\mathrm{AlOH}^{2+}+\mathrm{H}^{+}, \quad \mathrm{pH} \sim 5$.

Soil- $\mathrm{Na}^{+}+\mathrm{H}_{2} \mathrm{O}=$ Soil- $\mathrm{H}^{+}+\mathrm{Na}^{+}+\mathrm{OH}^{-}, \quad \mathrm{pH} \sim 9$.

The soil $\mathrm{pH}$ is evidently a major governing factor during the lime stabilization process, since high alkaline condition prevailing in the soil solution is indispensible to ensure complete dissolution of reactive silica and alumina from clay minerals [10]. During soil-lime interaction, the soil solution $\mathrm{pH}$ will rise due to excess supply of hydroxyl ions from lime dissociation and the long-term pozzolanic reactions are subsequently initiated at a high $\mathrm{pH}$ of 12.4 . However, $K T$ having low initial $\mathrm{pH}$ require more amount of lime to reach $\mathrm{pH} 12.4$ when compared to $N B T$ having higher $\mathrm{pH}$; hence, they exhibit diverse behaviour during lime stabilization. Thus, the OLC value of a soil with low initial $\mathrm{pH}$ will be higher than the one with higher initial $\mathrm{pH}$, provided other properties such as SSA, CEC, buffer capacity, etc., are remaining the same [31].

\section{Specific Surface Area and Charge Density}

The important soil properties such as extent of chemical reactivity, sorption affinity as well as expansive nature are 
predominantly governed by two major factors, being SSA (measured in $\mathrm{m}^{2} / \mathrm{g}$ ) and net surface charge/charge density (represented as charge per unit surface area) of clay mineral platelets present in the soil. The total SSA of clays includes both the internal (area of basal plane surfaces of each unit layer) and external (edges and faces of whole crystal) surface area. The non-expanding minerals such as $K T$ has only external surface, since the silica and alumina sheets are well packed in the micro-fabric arrangement without any inter-layer spaces (Fig. 1). Hence, most chemical reactivity and adsorption phenomena occur along the edges and surfaces of $K T$ microstructure [32]. Whereas, highly expanding montmorillonite has both internal/intralayer and external/inter-layer surfaces, ascribed to the loosely packed structural arrangement of adjacent clay mineral sheets by weak van der Waals forces. The SSA of clay minerals is normally measured to be $10-20 \mathrm{~m}^{2} / \mathrm{g}$ for $K T$ and $800 \mathrm{~m}^{2} / \mathrm{g}$ for montmorillonite [2].

The charge that originates at the clay surfaces is usually due to chemical interactions occurring at the mineral surface and pore fluid boundary; however, it can also be sourced by adsorption of anionic surfactants [33]. The clay minerals present in soil can generally have net negative or positive surface charges, owing to either the structural imbalance by broken bonds or substitution of cations having dissimilar valence. The total charge per unit surface area is defined as charge density, and classified as permanent and $\mathrm{pH}$-dependent charges depending on their cause of genesis [26]. The permanent charges to the clay surface are resulted primarily due to isomorphous substitution of similar sized ions in layered clay minerals, and seldom due to imperfections in clay structures as well [21]. For instance, if $\mathrm{Al}^{3+}$ is substituted by $\mathrm{Mg}^{2+}$ or $\mathrm{Si}^{4+}$ by $\mathrm{Al}^{3+}$ the negative charge of $\mathrm{O}^{2-}$ or $\mathrm{OH}^{-}$are left unsatisfied; hence, net negative charge develops. These charges are least dependent on $\mathrm{pH}$, and especially more important in case of 2:1 clay minerals such as montmorillonite than 1:1 clay minerals such as $K T$. This is mainly because of the absence of isomorphous substitution in $K T$, probably due to $1: 1 \mathrm{Si} /$ $\mathrm{Al}$ ratio and stronger hydrogen bonding of cations present on $K T$ surface [21]. However, kaolinitic soils with high amount of aluminium and iron oxides are characterized by strongly $\mathrm{pH}$ dependent surface charges. This is because $1: 1$ $K T$ mineral has relatively more edge area, and the $\mathrm{OH}^{-}$ ions present on edges contribute to $\mathrm{pH}$ dependent charges which constitute more than $50 \%$ of total negative charges on $K T$ surface. On the contrary, the 2:1 montmorillonite mineral has less edge area compared to basal plane area, and only $5-10 \%$ of total negative charges are $\mathrm{pH}$ dependent [20].

As mentioned before, the total SSA of clay minerals has direct influence on the reactive nature; consequently, the extent of lime stabilization varies with SSA value of concerned soil. The $K T$ having low SSA has less number of exchangeable sites available for lime fixation; therefore, less amount of lime is required to satisfy the charge deficiency and available excess free-lime will take part in longterm pozzolanic reactions. Whereas, $N B T$ having higher SSA require more lime content to fulfil the charge deficiency; thus, requires higher quantity of lime to achieve the desired degree of improvement. Taken as a whole, among two soils with different SSA values the one with higher SSA will have comparatively higher OLC value if the other factors such as initial $\mathrm{pH}$ and buffer capacity are same.

\section{Cation Exchange Capacity}

Cation exchange capacity, CEC is defined as the maximum quantity of total cations (both acid and base) that soil can hold at a given $\mathrm{pH}$, which are available for exchange with other cation species present in the soil solution [2]. The cations mentioned here are referred to any element with a positive charge (e.g., base cations such as $\mathrm{Ca}^{2+}, \mathrm{Mg}^{2+}, \mathrm{K}^{+}$, $\mathrm{Na}^{+}$, etc., and acid cations such as $\mathrm{H}^{+}$and $\mathrm{Al}^{3+}$ ). The soil with a high CEC can retain more number of cations owing to the large number of exchange sites available on the clay mineral surface. The strength of cation retention by soil particles increases with increasing ion charge and decreasing hydrated ion radius [20]. The relative cation replaceability, or ease of removal from specific colloids has been represented by 'lyotropic series', $\mathrm{Th}^{4+}>\mathrm{Fe}^{3+}>\mathrm{Al}^{3+}>$ $\mathrm{Cu}^{2+}>\mathrm{Ba}^{2+}=\mathrm{Sr}^{2+}>\mathrm{Ca}^{2+}>\mathrm{Mg}^{2+}>\mathrm{Cs}^{+}>\mathrm{Rb}^{+}>$ $\mathrm{K}^{+}=\mathrm{NH}_{4}^{+}>\mathrm{Li}^{+}>\mathrm{Na}^{+}$, in the order of decreasing strength of retention [2]. The relative extent of adsorption or desorption of ions primarily depend on the valence; for a given valence, degree of replaceability decreases as hydrated radius decreases. For instance, $\mathrm{K}^{+}$can be easily replaced by cations such as $\mathrm{Ca}^{2+}$ or $\mathrm{Mg}^{2+}$ since they have higher charge deposits. Similarly, $\mathrm{K}^{+}$is more strongly retained by soil compared to $\mathrm{Na}^{+}$because hydrated $\mathrm{K}^{+}$radius is smaller than hydrated radius of $\mathrm{Na}^{+}$. The highly unstable hydrogen ion $\left(\mathrm{H}^{+}\right)$is the only exception because it behaves like $\mathrm{La}^{3+}$ and produces $\mathrm{Al}^{3+}$ saturated clays by deposition. For clay minerals such as $K T$, CEC depends on soil $\mathrm{pH}$ also; it exhibits low CEC in acidic environment and high CEC in alkaline environment. As the $\mathrm{pH}$ of soil decreases all the exchange sites will be occupied by acid $\mathrm{Al}^{3+}$ and $\mathrm{H}^{+}$cations; particularly, those of which are least replaced by other base cations and eventually decreases the CEC value also [2].

CEC is usually expressed as milliequivalents of charge per $100 \mathrm{~g}$ (meq./100 g) of dry soil. A 'milliequivalent' is defined as the number of ions which corresponds to a specific quantity of electrical charges [34]. For e.g., 1 meq. of $\mathrm{K}^{+}$and $\mathrm{Ca}^{2+}$ corresponds to approximately $6 \times 1,020$ positive charges, but only $3 \times 1,020$ ions of $\mathrm{Ca}^{2+}$ because 
each $\mathrm{Ca}^{2+}$ cation has two positive charges [34]. The standard procedure of determining CEC of a soil involves saturation of clay mineral sites present in the soil with one cation; then washing out excess salt, and finally replacing the cation by several exchange/washing cycles with another cation. The concentration of replaced cation is measured from the decanted solution as CEC [35, 36]. Generally, clays and organic matter have electrostatic negative charges on surface and interstices, which can potentially attract and hold cations present in the pore solution [26]. As a result, soils having high clay and organic content exhibit high CEC. The high swelling montmorillonite clay mineral has very high CEC of $80-150$ meq./100 g followed by illite with $15-40$ meq./ $100 \mathrm{~g}$. On the contrary, heavily weathered/oxidised soil such as $K T$ exhibits very low CEC ranging from 1 to 15 meq./100 g [1]. Moreover, CEC of $K T$ is highly pH dependent which suggests that $\mathrm{OH}^{-}$dissociation from clay edges is the predominant source of charge rather than isomorphous substitution. In case of montmorillonite, the low inter-layer charges allow free expansion, and negative charge developed by isomorphous substitution on exposed internal and external surfaces effects in a higher permanent CEC [20].

When soil is treated with lime, the immediate interaction occurs in terms of cation exchange and consequent modification of plasticity properties. The addition of admixtures supplies excess of $\mathrm{Ca}^{2+}$ cations into the bulk solution which gets sorbed onto the soil surface by replacing dissimilar cations of relatively lesser valence from the exchangeable sites present in the soil, i.e., cation exchange phenomena $[37,38]$. The CEC of a soil strongly reflects the nature and proportion of expansive clay minerals rather than the total clay-size fraction; degree of crystallinity and particle size distribution are of lesser importance [4]. Further, the type and amount of clay minerals present in the soil have significant influence on the extent of pozzolanic reactions and degree of stabilization achieved. Therefore, it infers that CEC seems to be the primary step towards more permanent transformations during lime stabilization of fine-grained soils [39, 40].

\section{Zeta Potential}

The nature and crystallinity, crystal size and surface charge characteristics of metal oxides on clay platelets predominantly govern the sorption and/or desorption selectivity of ions by various clay minerals [41]. The charge distribution on any soil surface is expressed in terms of electrical potential developed at solid-liquid interface in response to relative movement of soil particles and water, also termed as zeta potential, ZP [42]. From a theoretical perspective, $\mathrm{ZP}$ is defined as the electric potential at the shear surface between stagnant and mobile parts of the electrolyte surrounding a charged particle moving in an electric field [43]. It is an intrinsic electro-kinetic property, particularly of clays, and closely related to fundamental chemico-mineralogical characteristics such as sorption affinity, buffer capacity, CEC, etc. The value of ZP varies with distance from the particle surface, surface composition of the particle, as well as type (valence and hydrated ion radius) and concentration of ions present in the pore solution [44]. The $\mathrm{ZP}$ is indirectly measured by calculating the electrophoretic mobility (EM) of particles in a dispersed soil suspension. It makes use of equipment called zeta meter, and $\mathrm{ZP}$ value can be calculated by using the Smoluchowski equation (Eq. 5) which gives direct relationship between ZP and EM [45-47]. This equation provides the most elementary expression for $\mathrm{ZP}$, and is expressed as follows.

$\zeta=\frac{4 \pi V_{\mathrm{t}}}{\varepsilon_{\mathrm{t}}} \times \mathrm{EM}$

where $\zeta$ is the zeta potential in $\mathrm{mV}$, EM is the electrophoretic mobility at specified temperature, $V_{\mathrm{t}}$ is the viscosity of suspending liquid and $\varepsilon_{\mathrm{t}}$ is the dielectric constant.

When an acid is added into soil solution, the increasing concentration of $\mathrm{H}^{+}$ions lowers the solution $\mathrm{pH}$. Following, adsorption of these $\mathrm{H}^{+}$ions onto the clay mineral surface will compress the DDL and lowers ZP value. Similarly, addition of alkali will increase concentration of $\mathrm{OH}^{-}$ions as well as $\mathrm{pH}$, and adsorption of $\mathrm{OH}^{-}$ions onto clay mineral surface increases DDL thickness and raises ZP $[48,49]$. Further, monovalent cations (viz., $\mathrm{Na}^{+}, \mathrm{K}^{+}$, etc.) give higher $\mathrm{ZP}$ (negative) than divalent cations (viz., $\mathrm{Ca}^{2+}, \mathrm{Mg}^{2+}$, etc.) because former are easily exchanged with $\mathrm{H}^{+}$ions in the system. This is also explained according to Gouy-Chapman model for DDL, which is given by Eq. 6 [2].

$\frac{1}{k}=\left[\frac{\varepsilon_{0} \varepsilon K T}{2 \eta_{0} e^{2} v^{2}}\right]^{1 / 2}$

where $1 / k$ is the thickness of DDL, $\varepsilon_{0}$ is the dielectric permittivity of vacuum, $\varepsilon$ is the dielectric constant of water, $K$ is the Boltzmann constant, $T$ is the absolute temperature, $\eta_{0}$ is the ion concentration, $e$ is the electron charge, and $v$ is the cation valence. From this equation, it is inferred that as the concentration and/or valence of ions increase, thickness of DDL decreases; thereby lowering the magnitude of $\mathrm{ZP}$ also (becomes less negative). For same ion valence, ZP decreases with increasing ion concentration up to neutral $\mathrm{pH}$, and thereafter, becomes positive. Moreover, for same valence a higher hydrated ion radius provides higher $\mathrm{ZP}$ as it gives thicker stern layer, and in turn thicker DDL.

For all the other properties being constant in a system, soil particles can exhibit zero value of electrical potential at a particular $\mathrm{pH}$ value called point of zero charge, pzc [50]. 
The zero charge indicates that there are only attractive forces between the particles, which cause flocculationagglomeration. In the presence of hydrolysable metal ions, clay minerals produce two pzc's, the former being a property of mineral itself obtained at acidic $\mathrm{pH}$ and the latter because of hydrolysable oxide precipitation at alkaline $\mathrm{pH}$ [51]. With hydrolysable ions, $\mathrm{ZP}$ of minerals becomes increasingly positive with increasing $\mathrm{pH}$, and reaches maximum at neutral $\mathrm{pH}$ (equal to $\mathrm{pH} 7$ ). Further, there is a decreasing trend towards negative direction, and maximum negative $\mathrm{ZP}$ occurs at around $\mathrm{pH} 10$. There can be variations for different metal ions depending on the concentration of ions and bulk precipitation $\mathrm{pH}$ of hydrolysable metals as hydrolysable oxides [51].

During lime treatment, cation exchange phenomena cause adsorption of $\mathrm{Ca}^{2+}$ ions on the negatively charged surface of clay minerals, which in turn reduces the DDL thickness and ZP [52-54]. As the concentration of lime increases, addition of excess $\mathrm{OH}^{-}$ions raises $\mathrm{pH}$ to that of saturated lime solution $(\mathrm{pH} \approx 12.4)$. At this highly alkaline $\mathrm{pH}$, the $\mathrm{ZP}$ becomes more negative and excess $\mathrm{Ca}^{2+}$ ions precipitate as hydroxide from bulk solution. This is detrimental because precipitation of calcium does not allow accurate measurement of ZP. Akbulut and Arasan [46] observed that addition of lime increases soil $\mathrm{pH}$ and decreases CEC, and ZP becomes more negative. The increasing cement content caused increase in $\mathrm{pH}$ and CEC, followed by increasing negative $\mathrm{ZP}$ up to $2 \%$ cement. Later, ZP moved to positive side. Conversely, fly ash addition reduced $\mathrm{pH}$ of the system and CEC, whereas $\mathrm{ZP}$ increased in negative direction. The decrease in CEC for lime and fly ash is owing to reaction of admixture with water instead of soil minerals and subsequent formation of new phases and reduction of water absorption potential. Further, Moayedi et al. [43] inferred that the negative charge on $K T$ surface is highly $\mathrm{pH}$ dependent, and the surface charge of pure $K T$ drops to zero at $\mathrm{pH}_{\mathrm{pzc}}$. The chemical admixtures which produce $\mathrm{pH}_{\mathrm{pzc}}$ closer to soil $\mathrm{pH}$ are considered to be most suitable for soil stabilization [43]. Taken as a whole, it is well understood that the initial $\mathrm{pH}$ of soil as well as type and concentration of ions present in soil solution determines the charge distribution on clay mineral surface; and hence, the electrokinetic properties such as ZP and electrical conductivity (EC). Therefore, the present study demands critical evaluation of $\mathrm{ZP}$ variations of selected soils during lime treatment, in order to comprehend the effects of soil $\mathrm{pH}$ on determination of OLC for stabilization of fine-grained soils.

\section{Soil Acidity}

Soil acidity is defined as the amount of total CEC of the soil occupied by acid cations (viz., $\mathrm{H}^{+}$and $\mathrm{Al}^{3+}$ ), and it is expressed in meq./100 $\mathrm{g}$ of soil [55]. For example, if the CEC and acidity number of a soil are 10 and 5 meq./100 g, respectively, it means that half of the exchange sites are occupied by $\mathrm{H}^{+}$and/or $\mathrm{Al}^{3+}$ acid cations. The remaining half of the sites is supposedly occupied by base cations (viz., $\mathrm{Na}^{+}$, $\mathrm{K}^{+}, \mathrm{Ca}^{2+}$ and $\mathrm{Mg}^{2+}$ ). The origin of acidity in a virgin soil can be attributed to various geochemical phenomena such as (a) natural chemical processes releasing $\mathrm{H}^{+}$ions, (b) carbonic acid formation by reaction of atmospheric carbon dioxide with water, (c) oxidation of ammonia, nitrogen, sulphur and iron, (d) presence of organic matter, (e) hydrolysis of aluminium ions, (f) natural deposition, and (g) environmental pollution. The sources of soil acidity are called pools of acidity, and are classified as active, exchangeable and residual pools [56]. The active acidity describes the quantity of $\mathrm{H}^{+}$ions in soil-water solution. The active pool of $\mathrm{H}^{+}$ions is in equilibrium with exchangeable $\mathrm{H}^{+}$ions, and can be easily measured using a $\mathrm{pH}$ meter. The quantity of $\mathrm{H}^{+}$and $\mathrm{Al}^{3+}$ ions occupying the exchange sites and contributing to $\mathrm{CEC}$ is referred as exchangeable acidity. Finally, the residual acidity denotes all strongly bound $\mathrm{H}^{+}$and $\mathrm{Al}^{3+}$ ions in the soil minerals, and these ions are least available for cation exchange. The relative quantities of $\mathrm{H}^{+}$and $\mathrm{Al}^{3+}$ in different pools of acidity can change as they move from pool to pool; hence, $\mathrm{H}^{+}$and $\mathrm{Al}^{3+}$ cations of one pool can replenish the deficiency of another pool, as a result of which soil gains enough resistance to change in $\mathrm{pH}$. For example, when $\mathrm{H}^{+}$and $\mathrm{Al}^{3+}$ are removed from the soil solution (active pool), the exchange sites (exchangeable pool) replenishes the deficit by supplying more $\mathrm{H}^{+}$and $\mathrm{Al}^{3+}$, and likewise, minerals containing strongly bound $\mathrm{H}^{+}$and $\mathrm{Al}^{3+}$ will dissolve and release these cations as they are removed from the exchangeable pool. This could also be a plausible reason for the dissolution of $\mathrm{Si}^{4+}$ and $\mathrm{Al}^{3+}$ at a high $\mathrm{pH}$ of 12.4 (corresponding to OLC as per $[10,13]$ ).

As acidity increases, soil $\mathrm{pH}$ decreases and more $\mathrm{H}^{+}$ ions are adsorbed on surface of colloids. These $\mathrm{H}^{+}$ions push the other cations from colloids into solution; and hence, CEC also decreases. As the soil becomes highly acidic and soil $\mathrm{pH}$ is very low (close to 0 ), all the exchangeable sites will be occupied by $\mathrm{H}^{+}$ions; and hence, the acidity number becomes same as CEC value itself. It is inferred that measurable amounts of $\mathrm{H}^{+}$ions are present in acidic soil solutions with $\mathrm{pH}$ less than 4 [20]. For $\mathrm{pH}$ between 4 and 5.5, $\mathrm{Al}^{3+}$ ions are predominantly measured with negligible quantity of $\mathrm{H}^{+}$ions. Further, soil solutions with $\mathrm{pH}$ 5.5-7 have no substantial exchangeable acidity because it primarily contains hydroxy aluminium polymers. Therefore, kaolinitic soils which have low $\mathrm{pH}$ and high acidity are characterized by low CEC value; whereas, montmorillonitic soils having high $\mathrm{pH}$ and low acidity exhibit high CEC value. Consequently, montmorillonitic soils require more amount of lime (i.e., OLC value) to supply sufficient $\mathrm{Ca}^{2+}$ ions for cation exchange, and 
initiating the long-term pozzolanic reactions compared to kaolinitic soils.

\section{Percentage Base Saturation}

Percentage base saturation is defined as the percentage of total ion exchange sites occupied by base cations, and represented as the fraction of exchangeable base cations in total CEC (shown in Eq. 7) [20]. If the total amount of exchangeable bases (viz., $\mathrm{Ca}^{2+}, \mathrm{Mg}^{2+}, \mathrm{K}^{+}, \mathrm{Na}^{+}$, etc.) present in a soil contributes to $100 \%$ of CEC, it means that there is no exchangeable acidity. For example, if $\mathrm{Ca}^{2+}$ and $\mathrm{Mg}^{2+}$ have base saturation of 75 and $20 \%$, respectively; it means that $\mathrm{Ca}^{2+}$ and $\mathrm{Mg}^{2+}$ occupy 3/4th and 1/5th of the total exchangeable sites, respectively. It is assumed that the remaining $1 / 20$ th is occupied by the acid cations. Similarly, if the percentage base saturation for a soil is 100 , then it is equal to total CEC of the soil itself. The total saturation (or CEC) of the soil refers to the sum of percentage base saturation and soil acidity, and it confirms whether all the exchange sites are occupied by cations.

Percentage base saturation

$$
=\frac{\Sigma(\text { exchangeable } \mathrm{Ca}, \mathrm{Mg}, \mathrm{K}, \mathrm{Na})}{\mathrm{CEC}} \times 100 .
$$

The concept of base saturation is important as it determines the $\mathrm{pH}$ of the soil in terms of relative proportions of bases and acids present on exchangeable sites. As the number of $\mathrm{Ca}^{2+}$ and $\mathrm{Mg}^{2+}$ base cations decreases and number of $\mathrm{H}^{+}$ and $\mathrm{Al}^{3+}$ acid cations increases, the soil $\mathrm{pH}$ drops. Since, neither exchangeable $\mathrm{Al}^{3+}$ nor $\mathrm{H}^{+}$ion is appreciable above pH 5.5 as discussed above percentage base saturation should be 100; for instance, montmorillonite has 100 percentage base saturation. However, for $K T$ even at $\mathrm{pH}$ above 5.5 percentage base saturation is less than 100 , because the charges are highly $\mathrm{pH}$ dependent; or in other words, 1:1 clay mineral has a low percentage base saturation compared to 2:1 clay mineral. When calcitic lime $\left(\mathrm{CaCO}_{3}\right)$ or dolomitic lime $\left(\mathrm{CaCO}_{3} \cdot \mathrm{MgCO}_{3} \cdot 2 \mathrm{H}_{2} \mathrm{O}\right)$ is added to soil the $\mathrm{Ca}^{2+}$ and/or $\mathrm{Mg}^{2+}$ base cations from lime replaces $\mathrm{H}^{+}$and $\mathrm{Al}^{3+}$ acid cations, consequently increasing the percentage base saturation and $\mathrm{pH}$ [38]. Hence, kaolinitic soil which exhibits low percent base saturation and low CEC value compared to montmorillonitic soils are characterized by lower OLC value also, as only less quantity of $\mathrm{Ca}^{2+}$ ions is required for cation exchange, and initiating the long-term pozzolanic reactions in kaolinitic soils.

\section{Buffer Capacity}

Buffer capacity is defined as the amount of $\mathrm{H}^{+}$or $\mathrm{OH}^{-}$ ions in the soil that must be neutralized in order to raise or drop the soil solution $\mathrm{pH}$ by one unit [57]. The buffer capacity of soil is dependent principally on two major factors, namely CEC and soil acidity (or BSC). As discussed in previous sections, soil acidity is controlled by the amount of $\mathrm{H}^{+}$and $\mathrm{Al}^{3+}$ ions that are either contained in, or generated by the soil and soil components. In general, soils with a high CEC have a greater potential to contain or generate these sources of acidity; i.e., they have enough resistance to change in $\mathrm{pH}$; and hence, higher buffer capacity as well. The standard titration method is generally adopted to measure the buffer capacity of soil, wherein, fixed volume of various molar concentrations of a dilute acid (e.g., $\mathrm{HNO}_{3}$ ) or base (e.g., $\mathrm{NaOH}$ ) solution is mixed with known quantity of soil [58]. The relationship of $\mathrm{pH}$ versus $\mathrm{cmol}$ of $\mathrm{H}^{+}$or $\mathrm{OH}^{-}$added is plotted, and the slope of the curve is referred as the buffer capacity of the soil [58-60]. For weathered surface soils, the relationship of $\mathrm{pH}$ versus $\mathrm{cmol}$ of $\mathrm{H}^{+}$or $\mathrm{OH}^{-}$added is observed to be linear over a $\mathrm{pH}$ range of 4.5-6.5 [61-63]. Therefore, it is recommended that buffer capacity should be quantified from the slope of the curve in the $\mathrm{pH}$ range following a linear trend in the titration curve.

When lime is added to soil as a buffer solution, the soil $\mathrm{pH}$ immediately increases due to immense supply of $\mathrm{OH}^{-}$ ions, and the resulting final $\mathrm{pH}$ is termed as buffer $\mathrm{pH}$ $(\mathrm{BpH})$. In soil science, the difference between the original $\mathrm{pH}$ of soil and $\mathrm{BpH}$ after lime reaction is used to suggest the lime recommendation for agricultural purposes [64, 65]. The more the difference between the two $\mathrm{pH}$ measurements, it reflects that soil $\mathrm{pH}$ is easily changed; and therefore, a low rate of liming will suffice. Moreover, soils having high CEC and buffer capacity do not need frequent liming when compared to low CEC soils. Nevertheless, when the soils become acidic due to various environmental influences, higher rate of liming is essential to attain the optimum $\mathrm{pH}$ level [64]. As a whole, it can be inferred that for a given $\mathrm{pH}$, a soil with a higher CEC (thus a lower $\mathrm{BpH}$ ) will normally require more lime to reach a given target $\mathrm{pH}$ than a soil with a lower CEC; and therefore, higher buffer capacity and OLC. Similarly, in the case of lime stabilization, the criteria of OLC (required to raise the soil $\mathrm{pH}$ to a desired value of 12.4) indirectly reflects the CEC and buffer capacity characteristics of concerned soil. In this way, comparing kaolinitic and montmorillonitic soils at same $\mathrm{pH}$, the former exhibit relatively lesser OLC as they have much lower CEC and buffer capacity compared to the latter.

\section{Experimental Investigations}

As discussed above, pioneer researchers have proposed different methods for determining the amount of lime 
required to satisfy the affinity of clay minerals and take part in chemical and pozzolanic reactions. Nonetheless, most of the studies failed to understand the primary influence of clay mineralogy upon lime reactivity and did not attempt to substantiate the reliability of the conventional tests. In the present study, the experimental validation of traditional OLC determination tests was conducted using wide range of soils such as commercially available $K T$ and $N B T$, as well as sandy clay $(S C)$, by employing commercially available calcium hydroxide $\left(\mathrm{Ca}[\mathrm{OH}]_{2}\right)$ of high purity as admixture. Initially, the virgin soils were characterized for their physical and geotechnical properties, and the results are presented in Table 1. The physical properties of soil such as specific gravity, SSA, pH corresponding to liquid-solid ratio of 10 [66], hygroscopic moisture content [67], consistency limits [68], grain size distribution [69] and classification [70, 71] were determined by following guidelines presented in the literature. Further, the compaction characteristics such as maximum dry unit weight and optimum moisture content were obtained as per ASTM D698 [72].

\section{Physico-chemical Properties of Virgin Soils}

The major physico-chemical properties of soil which infers its reactive nature include SSA and chemical composition

Table 1 Physical and geotechnical characteristics of virgin soils

\begin{tabular}{|c|c|c|c|}
\hline \multirow[t]{2}{*}{ Properties } & \multicolumn{3}{|c|}{ Soil types } \\
\hline & $K T$ & $N B T$ & $S C$ \\
\hline \multicolumn{4}{|l|}{ Physical characteristics } \\
\hline Specific gravity, $G$ & $2.64^{\mathrm{a}}$ & $2.73^{\mathrm{a}}$ & $2.69^{\mathrm{a}}$ \\
\hline Specific surface area $\left(\mathrm{m}^{2} / \mathrm{g}\right)$ & $87.3^{\mathrm{b}}$ & $757.7^{\mathrm{b}}$ & $284.2^{\mathrm{b}}$ \\
\hline $\mathrm{pH}$ & $5.3^{\mathrm{c}}$ & $10.3^{\mathrm{c}}$ & $9.0^{\mathrm{c}}$ \\
\hline Hygroscopic moisture content $(\%)$ & 1.3 & 11.9 & 3.7 \\
\hline \multicolumn{4}{|l|}{ Consistency limits (\%) } \\
\hline Liquid limit & 57 & 258 & 42 \\
\hline Plastic limit & 19 & 32 & 15 \\
\hline Plasticity index & 38 & 226 & 27 \\
\hline \multicolumn{4}{|c|}{ Grain size distribution characteristics ( $\%$ by weight) } \\
\hline Gravel size & 0 & 0 & 0 \\
\hline Sand size & 32 & 0 & 44 \\
\hline Silt size & 40 & 37 & 12 \\
\hline Clay size & 28 & 63 & 44 \\
\hline Unified soil classification system & $\mathrm{CH}$ & $\mathrm{CH}$ & $\mathrm{CI}$ \\
\hline \multicolumn{4}{|l|}{ Compaction characteristics } \\
\hline Maximum dry unit weight $\left(\mathrm{kN} / \mathrm{m}^{3}\right)$ & 15.9 & 12.9 & 16.9 \\
\hline Optimum moisture content $(\%)$ & 20.5 & 31.5 & 16.8 \\
\hline
\end{tabular}

(in terms of major chemical compounds) present in it. As previously mentioned, SSA of selected soils was assessed using ethylene glycol monoethyl ether (EGME) technique [73], and the obtained values are observed to be in the increasing order of $\mathrm{SSA}_{\mathrm{KT}}<\mathrm{SSA}_{\mathrm{SC}}<\mathrm{SSA}_{\mathrm{NBT}}$ (as shown in Table 1). The $\operatorname{SSA}_{\mathrm{NBT}}$ is measured to be approximately nine times that of $\mathrm{SSA}_{\mathrm{KT}}$ and two and half times SSA $\mathrm{SC}$, respectively. Similarly, the chemical characteristics were determined in the form of major oxides, using X-ray fluorescence (XRF) technique, and the obtained data are presented in Table 2.

Mineralogical and Micro-structural Properties of Virgin Soils

The mineralogical characteristics of virgin soils were determined by employing powder X-ray diffraction (XRD) technique (Philips make, model X'Pert PRO PANalytical, Netherlands) at working conditions of $45 \mathrm{kV}$ and $30 \mathrm{~mA}$, with $\mathrm{Cu} \mathrm{K} \alpha$ radiation, and the obtained X-ray diffractograms are presented in Fig. 3. The generated diffractograms were compared with the International Centre for Diffraction Data (ICDD) standard using 'PANalytical X'Pert HighScore Plus' software, and the different phases present in the samples were precisely identified. The diffractogram of $K T$ indicated the presence of significant amount of low swelling mineral, kaolin $(K T)$ as well as the non-clay minerals such as quartz. Similarly, for $N B T$ presence of $K T$, quartz and high swelling minerals such as montmorillonite were identified. The diffractogram of $S C$ consisted mostly of quartz, with traces of colusite, a tinbearing mineral belonging to the sphalerite group [74].

The micro-structural analysis was carried out using scanning electron microscope, SEM (Philips FEI make, model Quanta 200, USA) coupled with energy dispersive

Table 2 Chemical composition of soils

\begin{tabular}{llll}
\hline Chemical compound/property $(\%$ by weight) & \multicolumn{4}{l}{ Soil types } \\
\cline { 2 - 4 } & \multicolumn{2}{l}{ KT } & \multicolumn{2}{l}{$N B T$} & \multicolumn{2}{l}{$S C$} \\
\hline Silica $\left(\mathrm{SiO}_{2}\right)$ & 46.35 & 23.24 & 20.30 \\
Alumina $\left(\mathrm{Al}_{2} \mathrm{O}_{3}\right)$ & 20.85 & 8.43 & 5.46 \\
Ferric oxide $\left(\mathrm{Fe}_{2} \mathrm{O}_{3}\right)$ & 2.06 & 4.10 & 2.65 \\
Calcium oxide $(\mathrm{CaO})$ & 1.78 & 0.43 & 1.10 \\
Potassium oxide $\left(\mathrm{K}_{2} \mathrm{O}\right)$ & 1.79 & 0.42 & 1.55 \\
Titanium oxide $\left(\mathrm{TiO}_{2}\right)$ & 2.19 & 0.96 & 0.39 \\
Magnesium oxide $(\mathrm{MgO})$ & 0.22 & 0.72 & 0.59 \\
Sulphur trioxide $\left(\mathrm{SO}_{3}\right)$ & - & - & - \\
Alkali content $\left(\mathrm{Na}_{2} \mathrm{O}+\mathrm{K}_{2} \mathrm{O}\right)$ & 1.97 & 1.72 & 2.67 \\
Manganese oxide $(\mathrm{MnO})$ & 0.16 & 0.06 & 0.05 \\
Chloride $(\mathrm{Cl})$ & - & - & - \\
\hline
\end{tabular}

-: Below the detection limit of the instrument $(0.01 \%)$ 

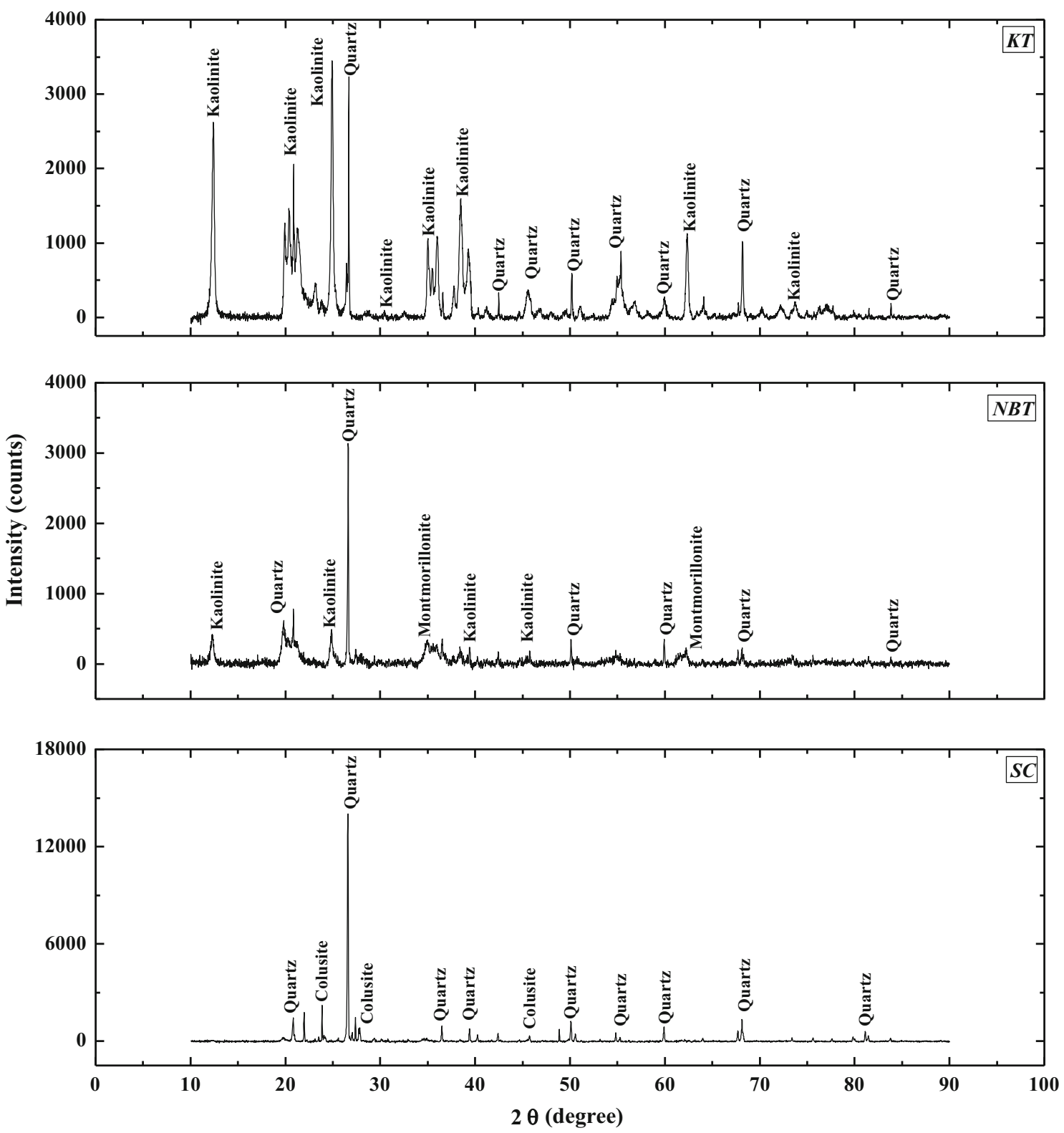

Fig. 3 Mineralogical characteristics of virgin soils

spectrometry $(E D S)$ facility for procuring the elemental composition of the respective samples. All the micrographs are obtained at a working condition of $30 \mathrm{kV}$ accelerating voltage and $10 \mathrm{~mm}$ working distance under high vacuum condition, and the EDS spectra are collected at working conditions of 20-30 s dwell time (DT), 1,000-2,000 counts per sec (CPS) and 100 live seconds (LS) with a scan rate of $102.5 \mu \mathrm{s}$. In the present study, a transmission electron microscope, TEM (Philips make, model CM12, USA) with Gatan charge-coupled device camera and lanthanum hexaboride filament was also used to evaluate the occurrence and nano scale structural features of individual particles present in the virgin soils. The working conditions followed in the present study are $<40$ vacuum pressure using ion-getter pump, $120 \mathrm{kV}$ high voltage, $23 \mathrm{~A}$ filament current and 5-8 $\mu \mathrm{A}$ emission current.

Figure 4 presents the $S E M$ and TEM micrographs along with $E D S$ spectra of virgin $K T, N B T$ and $S C$, respectively. From SEM micrographs, it is evident that $N B T$ has more fine particles which form flocs/aggregates by attractive forces; hence, more voids are clearly visible compared to $K T$ and $S C$. The EDS spectrum of $S C$ showed majority of silica $\left(\mathrm{Si}^{4+}\right.$ and $\left.\mathrm{O}^{2-}\right)$ representing sand and silt particles, and the background indicates the amorphous nature of the soil. Moreover, the EDS spectra of $K T$ and $N B T$ are in agreement with the XRD results (as shown in Fig. 3) which 

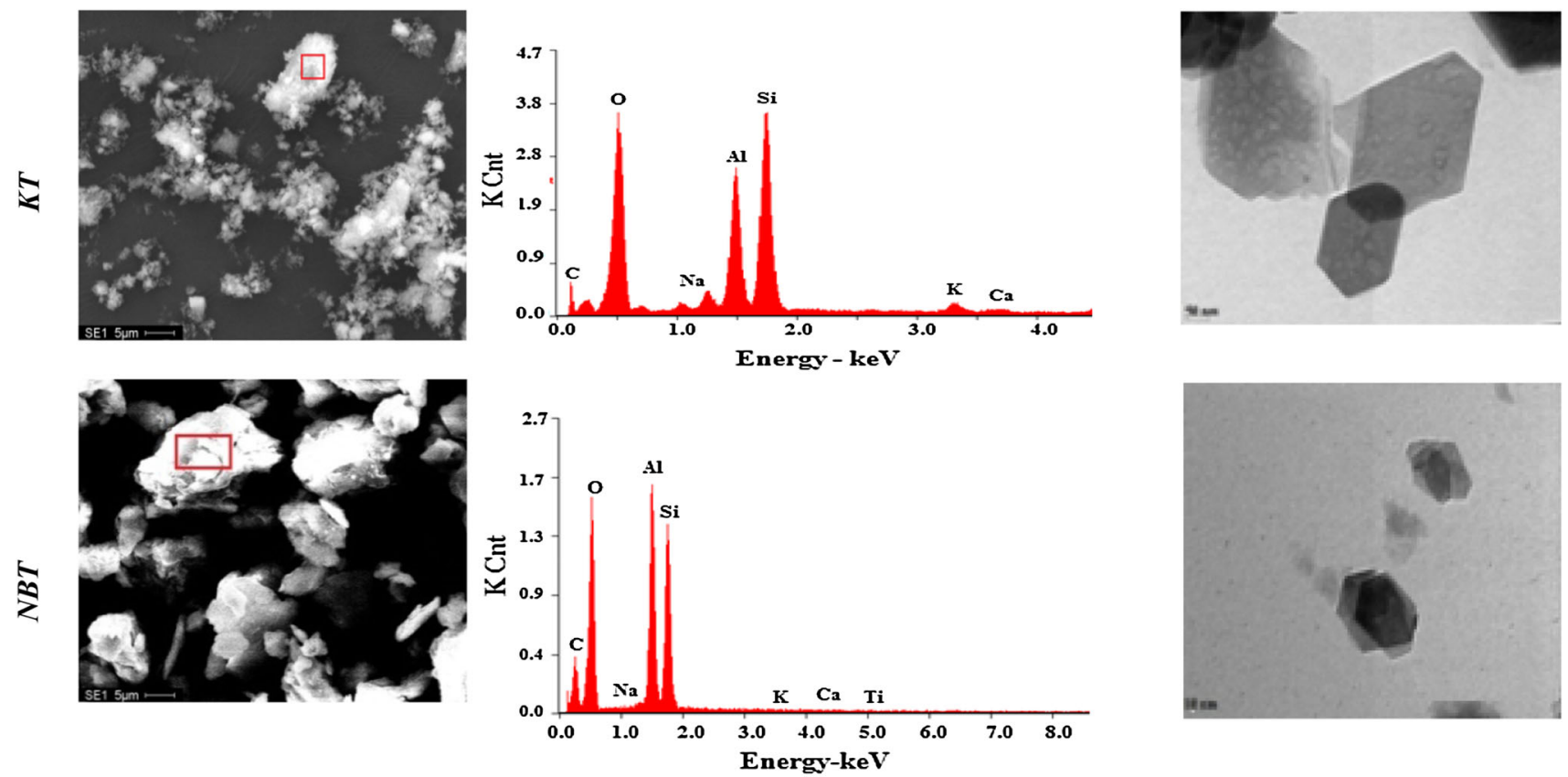

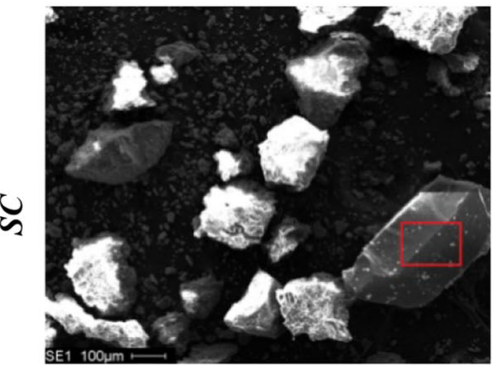

SEM micrograph

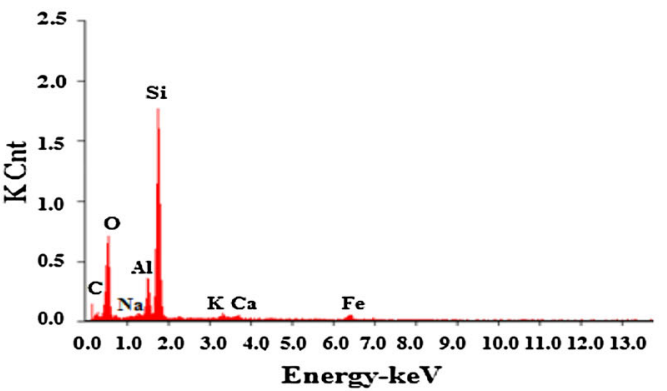

EDS spectrum

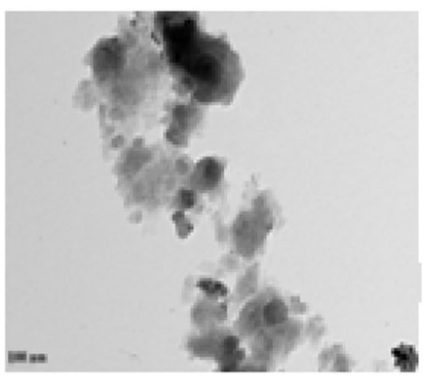

TEM micrograph

Fig. 4 Micro-structural and elemental composition of virgin soils

exhibit that both soil types are composed of largely $\mathrm{Si}$ and $\mathrm{Al}$, with traces of $\mathrm{Na}, \mathrm{K}$, and $\mathrm{Ca}$.

The TEM micrographs of $K T$ as well as $N B T$ (Fig. 4) showed presence of well-formed hexagonal rod shaped crystals, which further justifies the presence of 1:1 clay mineral $K T$ and 2:1 clay mineral montmorillonite, respectively [20] in the XRD results. However, the non-uniform particle size and shape observed in the micrograph of $S C$ suggests the absence of any clay mineral, which also supports the XRD results. The non-occurrence of clay minerals in $S C$ during micro-structural and mineralogical analyses is due to the sampling limitations.

\section{Cation Exchange Capacity and Base Saturation Capacity of Virgin Soils}

In the present study, the CEC of virgin soils was determined using the guidelines available in the literature and standards [34-36], and the results are presented in Table 3.
Initially, the virgin soil was mixed with hydrogen peroxide $\left(\mathrm{H}_{2} \mathrm{O}_{2}\right)$ and boiled thoroughly for $1 \mathrm{~h}$ to oxidize any organic matter present in it. Then, $5 \mathrm{~g}$ of oven dried treated sample was saturated with $\mathrm{Na}^{+}$by mixing with $50 \mathrm{ml}$ sodium acetate solution, $\mathrm{CH}_{3} \mathrm{COONa}$ of 1 normality at $\mathrm{pH}$ 5. The mixture was digested in a boiling water bath for 30 min with intermittent stirring and later, the sample was centrifuged at 1,000 $\mathrm{g}$ for $15 \mathrm{~min}$ (ELTEK make, Research Centrifuge model TC 4100D, India). The supernatant liquid was discarded and the soil sample settled at the bottom of the centrifuge tube was again treated with $50 \mathrm{ml}$ $\mathrm{CH}_{3} \mathrm{COONa}$ of 1 normality at $\mathrm{pH} 5$, digested and centrifuged. The process was repeated thrice to ensure complete saturation of exchangeable sites with $\mathrm{Na}^{+}$ion. Following, this sample was treated with $\mathrm{CaCl}_{2}$ solution (1 normality), and was again digested and centrifuged. The whole process was repeated thrice, in order to ensure complete replacement of $\mathrm{Na}^{+}$by $\mathrm{Ca}^{2+}$. This sample was again treated with $50 \mathrm{ml} \mathrm{CH}_{3} \mathrm{COONa}$ of 1 normality at $\mathrm{pH} 7$, and digested 
Table 3 Cation exchange- and base saturation capacity of virgin soils

\begin{tabular}{llclll}
\hline Soil types & $\mathrm{CEC}_{[\mathrm{Ca}]}($ meq./100 g) & $\mathrm{BSC}_{[\mathrm{Na}]}(\mathrm{meq} . / 100 \mathrm{~g})$ & $\mathrm{BSC}_{[\mathrm{K}]}($ meq./100 g) & $\mathrm{BSC}_{[\mathrm{Mg}]}(\mathrm{meq} . / 100 \mathrm{~g})$ & $\mathrm{TBSC}$ \\
\hline$K T$ & 42.3 & 0.0 & 3.5 & 235.6 & 281.4 \\
$N B T$ & 88.6 & 185.2 & 2.0 & 183.3 & 459.1 \\
$S C$ & 87.6 & 9.0 & 1.6 & 373.0 & 471.2 \\
\hline
\end{tabular}

and centrifuged thrice. The resulting supernatant was extracted and analyzed for concentration of $\mathrm{Ca}^{2+}$ using atomic absorption spectrometer (Thermo Scientific make, model iCE 3000, USA), and $\mathrm{CEC}_{[\mathrm{Ca}]}$ was calculated as per Eq. 8 [35]. the end of $24 \mathrm{~h}$, in order to evaluate the buffer capacity of soils. The tests were also repeated for various concentrations of $\mathrm{NaOH}$, and the titration curves for soil suspension $\mathrm{pH}$ versus $\mathrm{HNO}_{3} / \mathrm{NaOH}$ concentration in $\mathrm{cmol} \mathrm{H}^{+} / \mathrm{OH}^{-} / \mathrm{kg}$ soil were plotted for different soil samples as shown in

$\mathrm{CEC}_{[\mathrm{Ca}]}($ meq. $/ 100 \mathrm{~g})=\frac{\text { Concentration of } \mathrm{Ca}^{2+}(\mu \mathrm{g} / \mathrm{ml}) \times 100 \times \text { volume of extract }(\mathrm{ml})}{\text { Equivalent weight of the } \mathrm{Ca}^{2+} \text { ion } \times 1,000 \times \text { weight of sample }(\mathrm{g})}$

From the obtained results, it was observed that the $\mathrm{CEC}_{[\mathrm{Ca}]}$ of $K T, N B T$ and $S C$ followed the decreasing order of $S C>N B T>K T$. In addition, the total BSC $\left(\mathrm{TBSC}_{[\mathrm{Na}, \mathrm{K}, \mathrm{Ca}, \mathrm{Mg}]}\right)$ of soils was also determined by calculating the sum of major base cations $\mathrm{Na}^{+}, \mathrm{K}^{+}, \mathrm{Ca}^{2+}$, and $\mathrm{Mg}^{2+}$ in meq./100 $\mathrm{g}$ soil, by following guidelines presented in Clark [75]. From the results presented in Table 3, it was observed that TBSC of $K T, N B T$, and $S C$ followed the increasing order of $K T<N B T<S C$. However, maximum number of exchangeable $\mathrm{K}^{+}$and $\mathrm{Na}^{+}$cations were supplied by $K T$ and NBT, respectively. Similarly, $K T$ supplied minimum number of $\mathrm{Na}^{+}$and $\mathrm{Ca}^{2+}$ base cations, which in turn rationalizes its lowest $\mathrm{pH}$ when compared with $N B T$ and $S C$. The maximum amount of exchangeable $\mathrm{Mg}^{2+}$ cations was supplied by $S C$ followed by $K T$, and $N B T$ with least supply.

\section{Buffer Capacity of Virgin Soils}

The buffer capacity of virgin soils was determined by following the guidelines provided in the literature $[58,59]$, which employs conventional procedure of acid/base titration. Initially, different concentrations of $\mathrm{HNO}_{3}$ (acid) and $\mathrm{NaOH}$ (base) ranging from 0.02 to $0.2 \mathrm{~mol} / \mathrm{l}$ was prepared and stored in glass beakers. Later, different concentrations of soil- $\mathrm{HNO}_{3}$ mixtures were made by mixing $4 \mathrm{~g}$ soil with $40 \mathrm{ml} \mathrm{HNO}_{3}$ solution (liquid-solid ratio equals to 10 ) in polypropylene bottles. These solutions were placed in a mechanical shaker and continuously mixed for $24 \mathrm{~h}$ equilibration time. The $\mathrm{pH}$ of the samples was recorded at
Fig. 5. The $\mathrm{pH}$ of blank $\mathrm{HNO}_{3} / \mathrm{NaOH}$ solutions of different molar concentrations (in the absence of soil) was also recorded for reference in the respective titration plots.

In both acid and base titrations, $K T$ suspension indicated a lower initial $\mathrm{pH}$ of 5.5 than $N B T$ (pH 10.2) and $S C$ suspensions ( $\mathrm{pH}$ 9.4). As it can be observed from Fig. 5, the titration curve of $K T$ with $\mathrm{HNO}_{3}$ (dilute acid) indicates immediate drop in suspension $\mathrm{pH}$ with addition of $0.025 \mathrm{~mol} / 1 \mathrm{HNO}_{3}$ solution, and the $\mathrm{pH}$ variation with further acid input is negligible and also similar to that of the blank. This phenomenon clearly implies that the contribution of $K T$ for resistance to $\mathrm{pH}$ change is quite insignificant [59], and can be explained in terms of the very low CEC of $K T$, which in turn leads to a very low buffer capacity as well. In the titration curve of $N B T$, the suspension $\mathrm{pH}$ drops sharply from about $\mathrm{pH} 10.2$ to 2 when acid concentration reaches $0.1 \mathrm{~mol} / \mathrm{l}$. Beyond this point, little $\mathrm{pH}$ change is observed with further acid input. The $S C$ shows little resistance to change in $\mathrm{pH}$ value until acid concentration reaches $0.075 \mathrm{~mol} / \mathrm{l}$, beyond which $\mathrm{pH}$ starts to drop gradually from 1.7 to 0.6 .

The buffer capacity for each of the soils was deciphered from the negative slope of the respective titration curve of each soil, in the $\mathrm{pH}$ range which follows linear variation (between $\mathrm{pH} 4.5$ and 6.5). Accordingly, NBT has slightly higher buffer capacity $\left(13.4 \mathrm{cmol} \mathrm{H}^{+} / \mathrm{kg}\right.$ soil) than $S C$ (10.6 $\mathrm{cmol} \mathrm{H}^{+} / \mathrm{kg}$ soil), though the CEC of both soils are estimated to be approximately 90 meq./100 g soil. It can be interpreted that the relatively higher resistance to $\mathrm{pH}$ change in the $N B T$ is due to its better $\mathrm{H}^{+}$neutralization 

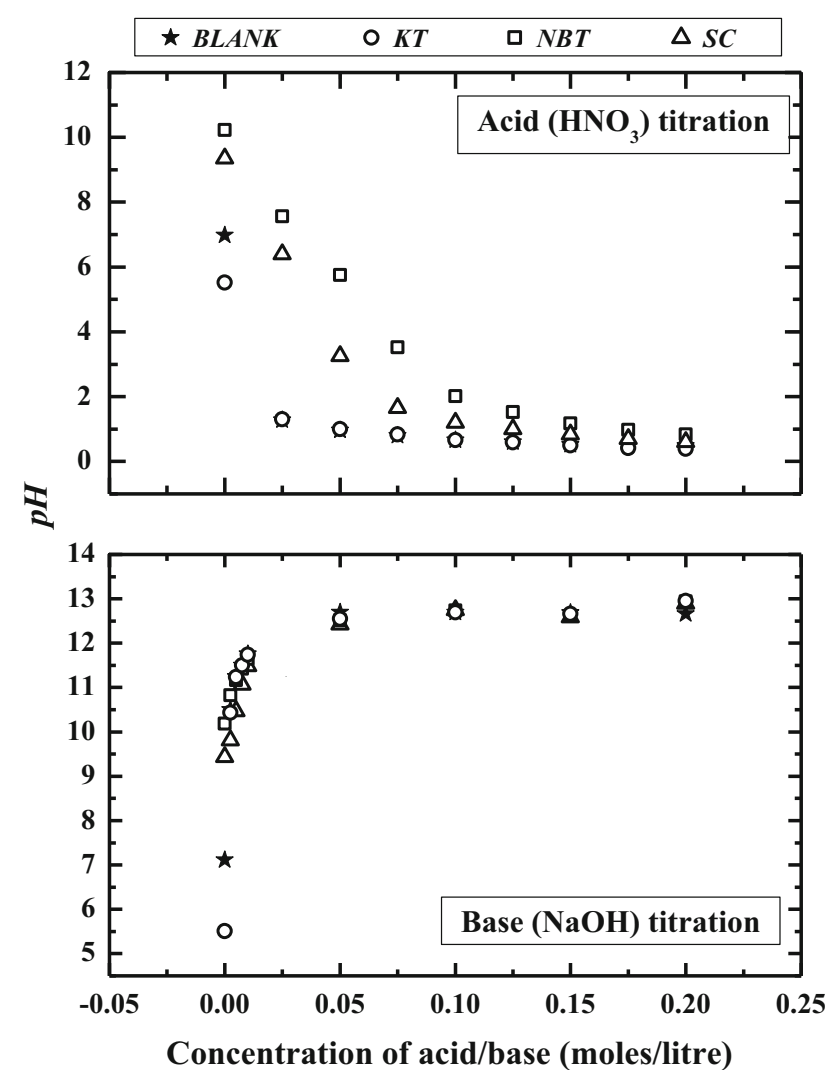

Fig. 5 Variation of soil $\mathrm{pH}$ with respect to acid and base concentration

capacity by adsorption into free exchange sites [20]. The $S C$ characterized by comparatively higher BSC is supposed to have less number of free exchange sites for $\mathrm{H}^{+}$ adsorption; and hence, less buffer capacity. Moreover, after reaching significant acid/base concentration the buffer capacity of all soils becomes trivial ( $\mathrm{pH}$ becomes equal to that of blank solution), probably because of adsorption of more $\mathrm{H}^{+}$ions by cation exchange, and free exchange sites are no longer available. Though, $K T$ does not represent any role in $\mathrm{pH}$ resistance, a fictitious buffer capacity value was determined from the initial slope of titration curve to be 5.9 cmol $\mathrm{H}^{+} / \mathrm{kg}$ soil.

Similarly, the titration curves of soils with $\mathrm{NaOH}$ (dilute base) were also plotted and analyzed for buffer capacity determination, as shown in Fig. 5. In this case, the titration curves of $K T, N B T$ and $S C$ displayed similar trends matching with the blank solution. The $\mathrm{pH}$ of all suspensions became more or less same beyond a certain concentration of $0.1 \mathrm{~mol} / \mathrm{l}$. However, the rate of change of $\mathrm{pH}$ with respect to base concentration was observed to be dissimilar for different soils for initial concentrations up to $0.01 \mathrm{~mol} / \mathrm{l}$. From the respective base titration curves, the buffer capacity for $K T, N B T$ and $S C$ was determined to be 1.8, 8.6, and $3.9 \mathrm{cmol} \mathrm{OH}^{-} / \mathrm{kg}$ soil, respectively.
Nevertheless, these values can be misleading; and hence, cannot be considered as true buffer capacity values since none of the soils exhibited resistance to change in suspension $\mathrm{pH}$ with respect to the blank solutions.

Taken as a whole, it can be deduced that all soils exhibited very little resistance to $\mathrm{pH}$ value changes on acid/ base input at the initial stages. This may be due to the fact that stronger $\mathrm{H}^{+}$ions supplied in the form of $\mathrm{HNO}_{3}$ are not initially available for cation exchange; and hence, $\mathrm{pH}$ changes rapidly upon the addition of very low concentrations of acid [58]. In case of base titration, by the addition of low concentrations of $\mathrm{NaOH}$, immediate attraction of lower valence $\mathrm{Na}^{+}$cations on to the negative clay platelet surface charges occur by weaker van der Waals forces $[2$, 26]. As a result, the increasing $\mathrm{OH}^{-}$concentration in the suspension cause sudden rise in $\mathrm{pH}$. As the acid/base concentration increases further resistance to $\mathrm{pH}$ change also increases, which is attributed to strong cation exchange reaction by replacing lower valence cations on clay surface by the higher valence cations present in the suspension [48]. In contrast to $N B T$ and $S C, K T$ apparently does not seem to have any substantial involvement in suspension $\mathrm{pH}$ variation. This phenomenon indicates that $K T$ has negligible CEC and reactivity towards electrolytes.

\section{Zeta Potential of Virgin and Lime-Treated Soils}

The ZP of soils was measured using zeta meter (make model Microtrac Zetatrac, Betatek, Inc., Canada) and Microtrac Flex 10.6.2 software package. The virgin soil was initially mixed with distilled water at liquid-solid ratio of 10 , and the suspension was kept for $24 \mathrm{~h}$ equilibration in a mechanical orbital shaker. Following, an aliquot (approximately $3 \mathrm{ml}$ ) of well dispersed solution was poured into the electrophoretic cell and ZP was measured for a set time of $20 \mathrm{~s}$. All the measurements were carried out at a working condition of $50-150 \mathrm{mV}$ applied voltage. The ZP of $N B T$ and $S C$ were measured to be -37.97 and $-21.24 \mathrm{mV}$, respectively. The observed high electro-negativity might have possibly risen from the charges accumulated by isomorphous substitution of $\mathrm{Al}^{3+}$ for $\mathrm{Si}^{4+}$ in the tetrahedral silica sheets of clay mineral. However, ZP of $K T$ could not be measured, owing to immediate settlement of clay particles due to its non-dispersive nature. As per literature, 1:1 KT mineral exhibits highly $\mathrm{pH}$ dependent $\mathrm{ZP}$ compared to 2:1 expansive minerals like montmorillonite $[49,76]$. The $\mathrm{ZP}$ values reported in literature ranges from -80 to $-25 \mathrm{mV}$ in the highly alkaline environment ( $\mathrm{pH} 9-12)$ and -25 to $+8 \mathrm{mV}$ in highly acidic environment ( $\mathrm{pH} 2-5)$. The $\mathrm{pH}$ dependent variable charges in $K T$ is probably due to protonation and de-protonation of surface hydroxyl groups present on edges and faces of octahedral alumina sheet of the clay mineral [49]. 
It is well understood that $\mathrm{pH}$ and $\mathrm{Ca}^{2+}$ cation concentration of soil-lime suspension determines the charge distribution on its clay mineral surfaces; and thereby, the rate of cation exchange reaction. This is in turn reflected in terms of the variations in electro-kinetic properties of limetreated soils such as ZP and EC. In view of this, the variations in ZP and EC for soils treated with different lime concentrations were also determined. For this, $10 \mathrm{~g}$ of virgin soil was mixed with different amounts of $\mathrm{Ca}(\mathrm{OH})_{2}$ up to $3 \%$ (by dry weight of soil), and the mixture was dissolved in $100 \mathrm{ml}$ distilled water. After $1 \mathrm{~h}$ equilibration in mechanical orbital shaker, the $\mathrm{pH}$ and EC of solutions were measured using water quality analyzer. Further, an aliquot taken from the same solution was used for determining ZP.

As shown in Fig. 6, the $\mathrm{pH}$ of $N B T$ and $S C$ became constant after addition of $1 \% \mathrm{Ca}(\mathrm{OH})_{2}$, as the soil-lime suspension attained the electrochemical properties of saturated lime solution. Based on the above observation, it can be presumed that precipitation of excess $\mathrm{Ca}(\mathrm{OH})_{2}$ occurs only after lime saturation [i.e., $1 \% \mathrm{Ca}(\mathrm{OH})_{2}$ by dry weight of soil]; and hence, no further remarkable changes occur in $\mathrm{pH}$. But, EC value continues to rise beyond $1 \%$ and up to $3 \% \mathrm{Ca}(\mathrm{OH})_{2}$ due to supply of cations from clay mineral surface by breaking of unstable bonds. Yet, another reason for constant $\mathrm{pH}$ might be the balanced adsorption of $\mathrm{OH}^{-}$ ions onto positive sites of clay minerals or desorption of $\mathrm{H}^{+}$ions by de-protonation of surface hydroxyl groups at high $\mathrm{pH}$ [77]. Also, at very high $\mathrm{pH} \mathrm{Ca}^{2+}$ cations are hydrolyzed as monovalent $\mathrm{CaOH}^{+}$ions and get adsorbed onto the de-protonated surfaces of clay minerals, and cause charge neutralization and lowering of suspension $\mathrm{pH}$ [77]. Another plausible reason for increase in EC value at a constant solution $\mathrm{pH}$ could be the relatively stronger dissolution of reactive $\mathrm{Si}^{4+}$ and $\mathrm{Al}^{3+}$ ions from the clay mineral surfaces into pore solution in the alkaline condition [78]. This shows that, even though the change in $\mathrm{pH}$ is solely due to change in $\mathrm{H}^{+}$and $\mathrm{OH}^{-}$concentration there is momentous influence from the dissolved cations (viz., $\mathrm{Si}^{4+}, \mathrm{Al}^{3+}, \mathrm{Mg}^{2+}, \mathrm{Na}^{+}$, etc.) as well, when it comes to variations in $\mathrm{EC}$ value.

Similarly, with increasing $\mathrm{Ca}(\mathrm{OH})_{2}$ concentration magnitude of $\mathrm{ZP}$ for $N B T$ initially decreased at a slow rate due to counteracting effect of $\mathrm{Ca}^{2+}$ and $\mathrm{OH}^{-}$ions, up to $0.25 \% \mathrm{Ca}(\mathrm{OH})_{2}$. From 0.25 to $0.75 \% \mathrm{Ca}(\mathrm{OH})_{2}$, magnitude of ZP decreased drastically owing to preferential adsorption and cation exchange reaction of $\mathrm{Ca}^{2+}$ with cations of lower valence on the clay platelet surface, in order to balance the net negative charge disequilibrium. The cation exchange reaction also resulted in high concentration build up of $\mathrm{Ca}^{2+}$ ions on clay platelet surface; thereby, increasing surface charge density and decreasing DDL thickness. Subsequently, the particles undergo
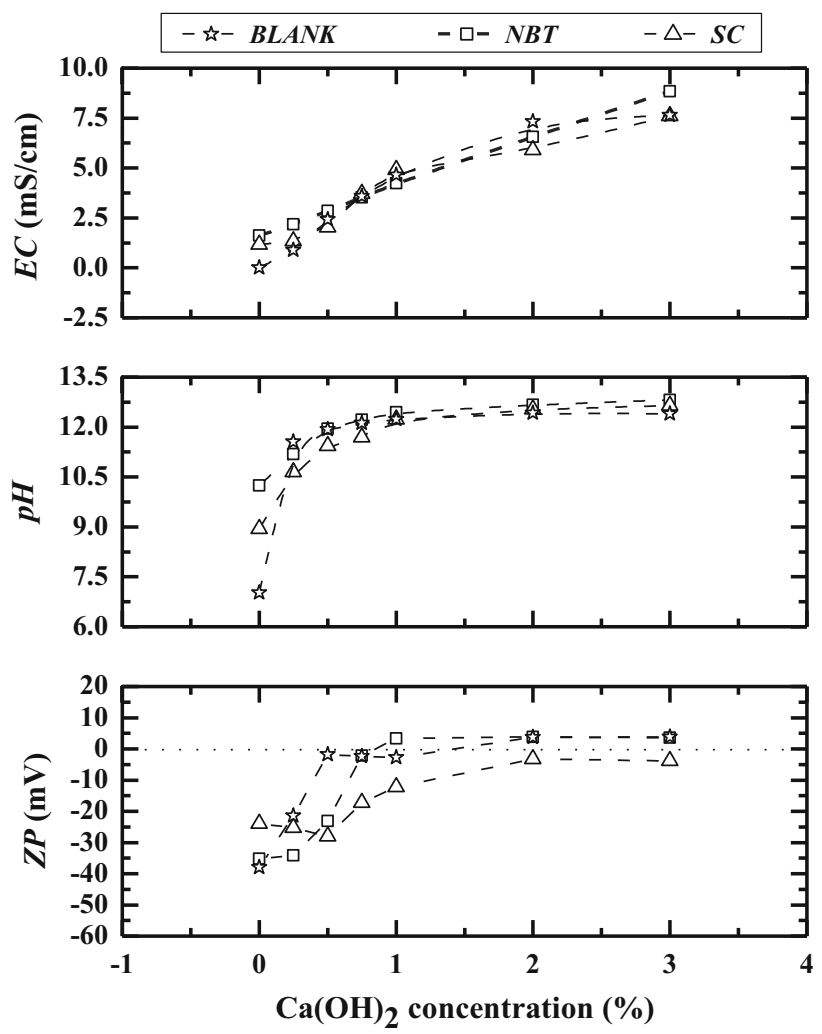

Fig. 6 Variation of electro-kinetic properties of soils with calcium hydroxide concentration

flocculation and $\mathrm{ZP}$ as well as affinity for $\mathrm{H}^{+}$ions decreases [54]. Beyond $1 \% \mathrm{Ca}(\mathrm{OH})_{2} \mathrm{ZP}$ becomes positive with 'pzc' at around $0.9 \% \mathrm{Ca}(\mathrm{OH})_{2}$, indicating that the lime fixation occurred at $0.9 \% \mathrm{Ca}(\mathrm{OH})_{2}$ and the charge affinity of all exchange sites are completely satisfied at this point. Similar trends were also obtained for $S C$ as well; however, rate of change of ZP is comparatively lesser and 'pzc' is observed at around $1.4 \% \mathrm{Ca}(\mathrm{OH})_{2}$ concentration. Beyond the highly alkaline $\mathrm{pH}$ of 12.4 , excess $\mathrm{Ca}^{2+}$ precipitates as hydroxide from bulk solution leading to constant $\mathrm{pH}$. At high $\mathrm{pH}$ the $\mathrm{ZP}$ is presumed to become increasingly negative by the adsorption of positively charged hydrolyzed species such as $\mathrm{CaOH}^{+}$ions on the surface of clay minerals [46]. However, from the present study ZP is observed to become constant, which might be owing to detrimental effects of calcium precipitation upon accurate measurement of ZP [52-54].

\section{Validation of Conventional Optimum Lime Content Determination Tests}

The OLC determination tests were conducted as per guidelines provided in literatures and standards [9-13], in terms of variations in plasticity characteristics, percentage 
Table 4 Determination of optimum lime content using conventional methods

\begin{tabular}{llllll}
\hline Soil types & Clay-size fraction $(\%)$ & \multicolumn{4}{c}{ OLC value in $\%$ as per } \\
\cline { 3 - 6 } & & {$[9]$} & {$[10]$} & {$[11]$} & {$[12]$} \\
\hline$K T$ & 28 & 2.1 & 0.8 & 2.8 & 2.0 \\
$N B T$ & 63 & 3.1 & 0.9 & 6.3 & 3.0 \\
$S C$ & 44 & 2.5 & 1.2 & 4.4 & 2.0 \\
\hline
\end{tabular}

clay fraction, activity of clay, etc. From the results obtained, as presented in Table 4, it can be observed that each method proposes dissimilar values for OLC required for soil modification. The test methods proposed by Hilt and Davidson [9] and Ingles and Metcalf [11] predicted the maximum OLC value for selected soils, and it theoretically accounts only for the total clay size fraction $(<2 \mu \mathrm{m})$ in the soil. However, it is well understood that only a percentage fraction of the total clay content possesses reactive nature; and hence, contributes towards pozzolanic reactions and soil stabilization. Therefore, these tests overestimate the OLC value of soils which constitute mostly non-reactive clay minerals as well as finer quartz and feldspar particles (especially, for $S C$ ). The method as per Nelson and Miller [12] predicted $L_{\mathrm{m}}$ value for all soils to be in the range of 2-3\% lime, beyond which the plasticity index became more or less constant with further addition of lime probably due to the influence of operational error in determining plasticity characteristics. In addition, this method only considered the maximum amount of $\mathrm{Ca}^{2+}$ ions fixed onto available exchange sites on clay minerals and modifies plasticity of soil; and yet, does not consider the long-term pozzolanic reactions.

From the Eades and Grim test [10], the OLC for $K T$, $N B T$ and $S C$ was determined to be $0.8,0.9$ and $1.2 \%$, respectively, and is observed to be the lowest when compared to other three methods. From this observation, it is also inferred that Eades and Grim method assessed only the minimum lime content required to produce a soil-limewater $\mathrm{pH}$ of 12.4 , and does not account for the availability of free calcium ions to drive pozzolanic reactions. Hence, it can be concluded that the presently adopted quick tests does not give a clear indication about the OLC required for effective stabilization. Further, it is also realized that all these methods assess the amount of lime corresponding to lime fixation point, the stage in which all cation exchange reactions are complete, and $\mathrm{pH}$ of suspension is sufficiently high for complete dissolution of reactive clay minerals from soil. Though, lime fixation modifies the plasticity and swelling characteristics of fine-grained soils to reasonable extent, the excess amount of free-lime which is indispensable for long-term pozzolanic reactions is not accounted.
The OLC value determined for $K T$ and $N B T[\approx 1 \%$ $\mathrm{Ca}(\mathrm{OH})_{2}$ ] as per Eades and Grim test [10] are quite below the values reported in previous literatures. As per previous researchers [5, 79-81], clayey soils having initial $\mathrm{pH}$ value in the range of $8-10$ exhibited $6-8 \% \mathrm{Ca}(\mathrm{OH})_{2}$ as OLC value from standard $\mathrm{pH}$ test [13]. Further, many literatures showed that soils rich in $K T$ and bentonite clay minerals require OLC value of 3-6\% to attain $\mathrm{pH} 12.4$ as per Eades and Grim test [6, 82-86]. However, in the present analysis both $K T$ and $N B T$ are observed to have reached lime fixation at an OLC value of approximately $1 \% \mathrm{Ca}(\mathrm{OH})_{2}$, which is ambiguous. It is also observed from the variation of $\mathrm{ZP}$ with $\mathrm{Ca}(\mathrm{OH})_{2}$ concentration (as shown in Fig. 6) that ZP reached zero (corresponding to 'pzc') at approximately 0.9 and $1.4 \% \mathrm{Ca}(\mathrm{OH})_{2}$, respectively for $N B T$ and $S C$ suspensions. The slight difference between 'pzc' value of $1.4 \% \mathrm{Ca}(\mathrm{OH})_{2}$ and $\mathrm{OLC}$ value of $1.2 \% \mathrm{Ca}(\mathrm{OH})_{2}$ for $S C$, might be attributed to manual and experimental inconsistency. As the tests performed in this study derives more or less same OLC value for all soils with negligible margin, it contradicts the inferences from literature which suggest that $K T$ being a low reactive mineral is characterized by lower OLC compared to $N B T$ having very high reactive nature. It is inferred that due to plausible interplay of so many inherent parameters such as clay mineralogy it becomes quite difficult to precisely estimate OLC, which would have the most significant influence on the efficacy and extent of stabilization in fine-grained soils.

\section{Influence of Clay Mineralogy on Optimum Lime Content}

The ASTM standard test [13] conducted to determine the OLC for lime stabilization of fine-grained soils recommends a minimum of $2 \%$ lime content to initiate the test. This could be attributed to the buffer capacity of the virgin soil, generally 1-3\% [6]. However, all soils in the present study exhibited an OLC value less than $2 \%$, which infers that the actual value of OLC may vary depending upon the mineralogical properties and reactivity nature of different soils. In addition, it is gathered that for two soils having same CEC and buffer capacity, the OLC will ultimately vary depending on its initial $\mathrm{pH}$ value. This is probably due to the fact that the soil having high initial $\mathrm{pH}$ will require less lime to reach $12.4 \mathrm{pH}$; and hence, exhibits lower OLC value. Nevertheless, none of the conventional methodologies presented in the literature considered these possible counter effects from initial soil $\mathrm{pH}$ during the determination of OLC. From the above inferences, it is opined that more rigorous attempts are essential to develop and establish unique correlations between OLC and important clay mineral characteristics. In view of this, further analyses were carried out in order to substantiate the influence 


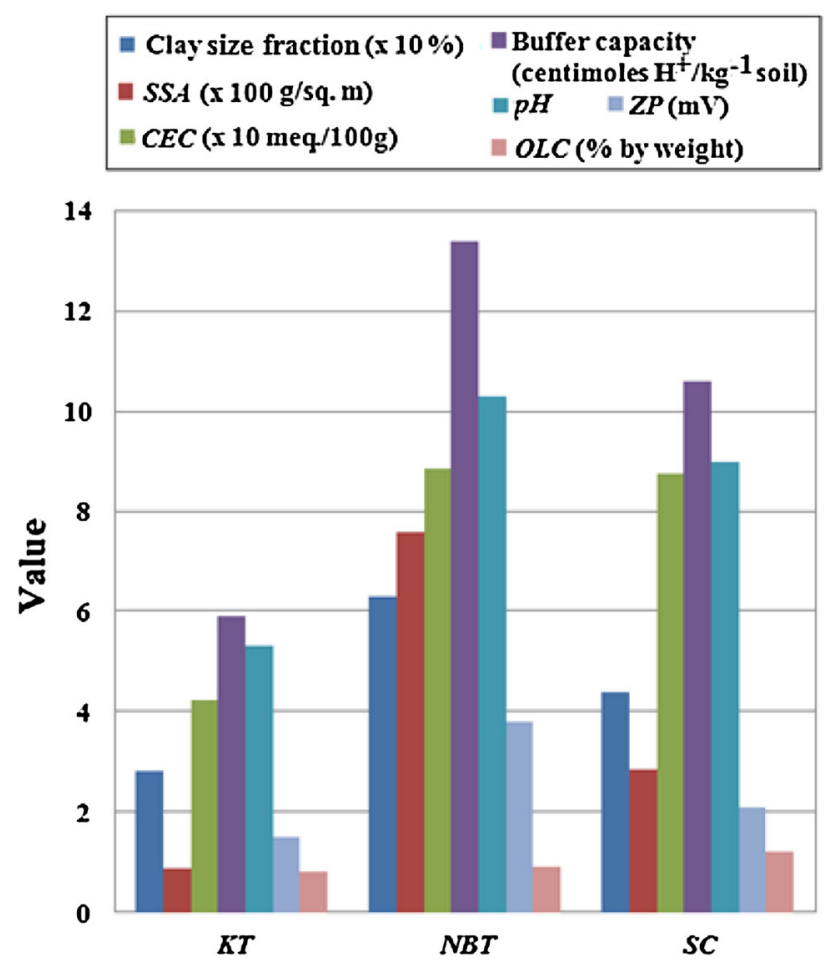

Fig. 7 Influence of clay mineralogical characteristics on OLC

of clay mineralogy on the determination of OLC for longterm stabilization of fine-grained soils.

The inherent physical and mineralogical properties (viz., clay-size fraction, $\mathrm{pH}$, SSA, CEC, buffer capacity, ZP, etc.) of selected soils and measured OLC value were compared and correlated graphically (as shown in Fig. 7). From the observations, it can be well affirmed that clay-size fraction as well as SSA follows the increasing order of $K T<S C<N B T$. This is attributed to the cumulative effect of external as well as internal (intra- and inter-clay layer) SSA associated with individual clay particles present in the soils. Similarly, $K T$ having lowest clay mineral content is also characterized by relatively lower CEC as well as buffer capacity compared to $N B T$ and $S C$. The decrease in CEC with decreasing clay content is attributed to lesser SSA, and consequently, less number of ion exchange sites available per unit weight of soil. Moreover, the linearly proportional relationship between CEC and buffer capacity intimates that soils having higher CEC supply more number of cations to satisfy the deficiency in pore solution; and hence, can resist any change in solution $\mathrm{pH}$ to relatively higher extent.

In addition, it is observed that a higher CEC and TBSC results in higher ZP and buffer capacity ascribed to the dissociation of silica and alumina hydroxyl groups at high $\mathrm{pH}$, which consequently increases negative charges on surface of clay minerals, and also neutralizes $\mathrm{H}^{+}$ion concentration in pore solution by supplying $\mathrm{OH}^{-}$ions. Thus, $K T$ having an acidic $\mathrm{pH}$ is characterized by very low $\mathrm{CEC}$ and $\mathrm{ZP}$, while $S C$ and $N B T$ having basic $\mathrm{pH}$ exhibits high CEC and ZP values. In spite of all these observations, the OLC value obtained for soils did not match with other properties such as CEC, and buffer capacity. Though $K T$, $N B T$, and $S C$ possessed widely varying mineralogical characteristics (refer to Fig. 7), the OLC values of all soils are observed to be approximately $1 \%$. This contradiction further strengthens the assumption that the high $\mathrm{pH}$ of $N B T$ (pH 10.3) and $S C$ (pH 9.0) literally nullifies the influence of CEC and buffer capacity up on its OLC value determined as per Eades and Grim test [10].

Based on the above discussions on various theoretical clay mineralogy concepts, it is quite evident that the most critical parameters in lime treatment, namely, ICL and OLC are rather more complex and involved than the contemplations of previous researchers. Though the conventional tests mainly take into account the clay content and plasticity characteristics of soils; yet, they do not account for the indispensible role played by soil-lime compatibility, in terms of chemico-mineralogical characteristics of virgin and treated soils. Further, the present study brings out more specific observations that the standard tests employed for OLC determination [10,13] based on the principle of attaining optimum solution $\mathrm{pH}$ of 12.4 , indirectly accounts for CEC and buffer capacity of clay minerals as well. During lime stabilization process, the beneficiary is interested in improving the long-term strength and durability of the virgin soil by enhancing the pozzolanic reactions. In order to achieve this, sufficient amount of free $\mathrm{Si}^{4+}$ and $\mathrm{Al}^{3+}$ ions must be available in the pore solution, the dissolution of which occurs at a high $\mathrm{pH}$ 12.4. Therefore, the amount of lime that can raise the $\mathrm{pH}$ of soil solution to a target $\mathrm{pH} 12.4$ is considered as OLC, which primarily depends on buffer capacity of the soil. The soil types having high buffer capacity will attain $\mathrm{pH} 12.4$ at a rather slower rate; and hence, the OLC will be higher when compared to those having low buffer capacity. From all these observations, we can confidently state that the OLC value characteristically reflects the buffer capacity of the soil which is predominantly influenced by CEC of the soil. Yet, the critical synthesis of available literature suggests that the so measured OLC is the minimum amount of lime only sufficient enough to create favourable conditions for dissolution of reactive clay minerals, but does not supply adequate amount of free $\mathrm{Ca}^{2+}$ ions to take part in the long-term pozzolanic reactions and improve permanent soil strength. Thus, it is further proved that Eades and Grim test is not a reliable method for determination of OLC for stabilization of fine-grained soils. In addition to the standard ASTM test, the determination of unconfined compressive strength of lime-treated soils is indispensible for 
identifying the limiting lime content which can provide maximum strength and durability for stabilized soils.

\section{Conclusions and Summary}

From the critical appraisal of literature pertaining to lime stabilization of fine-grained soils, it is gathered that the researchers implemented several rules of thumb with nebulous concepts, and less conservative approaches for determining OLC required to adequately stabilize and strengthen problematic clayey soils. However, these methodologies have an element of risk, since lime contents marginally above or below the optimum can impart dramatic effects on strength and long-term durability of treated soil matrix. In view of these presumptions, the authors try to bring to focus the fundamental reaction mechanisms involved during OLC determination tests, as well as in situ stabilization. Further, attempts have been made to evaluate the substantial role played by mineralogical characteristics of soil over immediate modification and long-term stabilization of lime-treated soils. The major conclusions which could be drawn from the present study are listed as follows.

- $\quad K T$ has a lower OLC compared to NBT and $S C$ because by the addition of lime $K T$ attains $\mathrm{pH} 12.4$ at a faster rate due to its poorer CEC and buffer capacities. From this, it is hypothesized that OLC has no direct impact on pozzolanic reactions; but, it only provides a suitable condition for easy dissolution of $\mathrm{Si}^{4+}$ and $\mathrm{Al}^{3+}$ ions required for long-term soil-lime interaction.

- The initial $\mathrm{pH}$ of $N B T(\mathrm{pH} 10.2)$ and $S C(\mathrm{pH} \mathrm{9.0)} \mathrm{is}$ very high compared to $K T$ ( $\mathrm{pH} 5.5$ ); hence, the effect of low buffer capacity of $K T$ on OLC is literally nullified. Consequently, the OLC remains almost same $(\approx 1 \%$ lime) as same amount of lime eventually bring $\mathrm{pH}$ to 12.4 for both soils.

- The protocol of Eades and Grim test is true only in terms of rise in solution $\mathrm{pH}$ to 12.4 essentially required for initiating pozzolanic reactions, which is eventually caused by increased $\mathrm{OH}^{-}$ions concentration supplied by lime. Yet, this test does not provide reliable and substantial information relative to either potential reactivity of particular soil, or magnitude of increased strength realized upon its treatment with OLC.

Based on the implications derived from the present study, it is assessed that soil-lime interaction during stabilization process is a more complex and involved phenomena. Hence, it is recommended that any attempt to obtain more consistent and precise correlations for OLC determination based on concept of clay mineralogy will be beneficial. Moreover, thorough laboratory testing needs to be undertaken [viz., standard tests for unconfined compressive strength and California bearing ratio (CBR) evaluation] for determination of OLC, where long-term strength gain is the primary concern. The research in progress anticipates to establish a generalized relationship between OLC and various fundamental parameters: essentially, $\mathrm{pH}, \mathrm{CEC}$ and BSC, buffer capacity, curing time, and geotechnical properties (viz., compaction characteristics, consistency indices, coefficient of permeability, unconfined compressive strength, etc.). Further, it is anticipated to culminate in developing a predictive model, which can become a reference/guideline for the field engineers to determine the OLC for wide range of virgin soil properties.

\section{References}

1. Arabi M (1986) Fabric and strength of clays stabilized with lime. Dissertation, The Polytechnic of Wales, UK

2. Mitchell JK, Soga K (2005) Fundamentals of soil behaviour, 3rd edn. Wiley, New York

3. Kavak A, Baykal G (2012) Long term behaviour of lime-stabilized kaolinite clay. Environ Earth Sci 66:1943-1955

4. Croft JB (1968) The problem in predicting the suitability of soils for cementitious stabilization. Eng Geol 2(6):397-424

5. Ciancio D, Beckett CTS, Carraro JAH (2014) Optimum lime content identification for lime-stabilized rammed earth. Constr Build Mater 53:59-65

6. Bell FG (1996) Lime stabilization of clay minerals and soils. Eng Geol 42:223-237

7. Jung C, Bobet A (2008) Post-construction evaluation of limetreated soils. Joint Transport Research Program Technical Reports, No. FHWA/IN/JTRP-2007/25, pp 1-231

8. Dash SK, Hussain M (2012) Lime stabilization of soils: reappraisal. J Mater Civ Eng 24(6):707-714

9. Hilt GH, Davidson DT (1960) Lime fixation in clayey soils. Highw Res Board Bull 262:20-32

10. Eades JL, Grim RE (1966) A quick test to determine lime requirements for soil stabilization. Highw Res Rec 139:61-72

11. Ingles OG, Metcalf JB (1972) Soil stabilization: principles and practice. Butterworths, Melbourne

12. Nelson JD, Miller DJ (1992) Expansive soils: problems and practice in foundation and pavement engineering. Wiley, New York

13. ASTM D6276-99a (2006) Standard test method for using $\mathrm{pH}$ to estimate the soil-lime proportion requirement for soil stabilization. ASTM International, West Conshohocken

14. BS 1924-2 (1990) Stabilized materials for civil engineering purposes, methods of tests for cement-stabilized and lime-stabilized materials-part 2. British Standards Institution, London

15. Rogers CDF, Glendinning S, Roff TEJ (1997) Lime modification of clay soils for construction expediency. Proc Inst Civ Eng Geotech Eng 125(4:1):242-249

16. Puppala AJ, Wattanasanticharoen E, Punthutaecha K (2003) Experimental evaluations of stabilisation methods for sulphaterich expansive soils. Ground Improv 7(1):25-35

17. Little DN (1987) Evaluation of structural properties of lime stabilized soils and aggregates. National Lime Association. http:// 02fcdb0.netsolhost.com/documents/publications/free_downloads/ soils-aggregates-vol1.pdf. Accessed 15 Sep 2012

18. Clara H, Handy RL (1963) Characteristics of lime retention by montmorillonitic clays. Highw Res Rec 29:55-69 
19. Basma A, Tuncer ER (1991) Effect of lime on volume change and compressibility of expansive clays. Transp Res Rec 1295:52-61

20. Bohn HL, McNeal BL, O'Connor GA (2002) Soil chemistry. Wiley, New York

21. Sposito G (2008) The chemistry of soils. Oxford University Press, Oxford

22. Murray HH (2006) Applied clay mineralogy: occurrences, processing and applications of kaolins, bentonites, palygorskitesepiolite, and common clays. Elsevier, Amsterdam

23. Mukherjee S (2013) The science of clays: applications in industry, engineering, and environment. Springer, Berlin

24. García-Romero E, Vegas J, Baldonedo JL, Marfil R (2005) Clay minerals as alteration products in basaltic volcaniclastic deposits of La Palma (Canary Islands, Spain). Sediment Geol 174(3):237-253

25. Riuz C (2006) Genesis and evolution of the kaolin-group minerals during the diagenesis and the beginning of metamorphism. University of Málaga, Málaga, pp 41-52

26. Olphen HV (1963) An introduction to clay colloid chemistry: for clay technologists, geologists, and soil chemists. Interscience Publishers, London

27. McLean EO (1982) Soil pH and lime requirement. In: Methods of soil analysis, Part 2-chemical and microbiological properties. American Society of Agronomy, Inc., Soil Science Society of America, Inc., Madison, pp 199-224

28. Pansu M, Gautheyrou J (2007) Handbook of soil analysis: mineralogical, organic and inorganic methods. Springer, Berlin

29. Maghami S, Nikoodel A (2012) Cation exchange and its role on soil behaviour. Slideshare. http://www.slideshare.net/Shahram Maghami/cation-exchange-and-its-role-on-soil-behaviour. Accessed 30 Dec 2013

30. Ouhadi VR, Goodarzi AR (2007) Factors impacting the electro conductivity variations of clayey soils. Iran J Sci Technol 31(B2):109-121

31. Bandipally S, Cherian C, Arnepalli DN, Pooja CP (2014) Influence of $\mathrm{pH}$ on long term performance of lime stabilized finegrained soils. In: Proceedings of Indian geotechnical conference2014, Kakinada, India

32. Miranda-Trevino JC, Cynthia AC (2003) Kaolinite properties, structure and influence of metal retention on $\mathrm{pH}$. Appl Clay Sci 23:133-139

33. Stumm W, Morgan JJ (1981) Aquatic chemistry: an introduction emphasizing chemical equilibria in natural waters. Wiley, New York

34. Mengel DB (1914) Fundamentals of soil cation exchange capacity (CEC). Agronomy Guide. Purdue University, AY 238

35. IS: 2720-Part XXIV (1976) Methods of test for soils: determination of cation exchange capacity. Bureau of Indian Standards, New Delhi

36. ASTM D7503-10 (2010) Standard test method for measuring the exchange complex and cation exchange capacity of inorganic fine-grained soils. ASTM International, West Conshohocken

37. Ma C, Eggleton RA (1999) Cation exchange capacity of kaolinite. Clays Clay Miner 47(2):174-180

38. Marshall RT (1967) Factors influencing the plasticity and strength of lime-soil mixtures. Eng Exp Stn Bull 492:1-19

39. Koslanant S (2006) Influence of storage conditions on geotechnical properties of Ariake clay and on its chemical stabilization. Dissertation, Saga University Graduate School of Science and Engineering

40. Choquette M, Berube M, Locat J (1987) Mineralogical and microtextural changes associated with lime stabilization of marine clays from eastern Canada. Appl Clay Sci 2:215-232

41. Violante A, Krishnamurti GSR, Pigna M (2008) Factors affecting the sorption-desorption of trace elements in soil environments. In: Biophysico-chemical processes of heavy metals and metalloids in soil environments. Wiley, New York, pp 169-213
42. Sparks DL (1988) Soil physical chemistry. CRC Press, Boca Raton

43. Moayedi H, Huat BBK, Kazemian S, Mohammad TA (2012) Effect of stabilizer reagents on zeta potential of kaolinite and its relevance to electrokinetic treatment. J Dispers Sci Technol 33:103-110

44. Angle CW, Hamza HA (1989) An electrokinetic study of a natural coal associated mixture of kaolinite and montmorillonite in electrolytes. Appl Clay Sci 4:263-278

45. Smoluchowski MV, Graetz L (1921) Handbuch der Elektrizität und des Magnetismus. Band II, vol 2. Barth-Verlag, Leipzig, pp 366-428

46. Akbulut S, Arasan S (2010) The variations of cation exchange capacity, $\mathrm{pH}$, and zeta potential in expansive soils treated by additives. Int J Civ Struct Eng 1(2):139-154

47. Sharma NK, Swain SK, Sahoo UC (2012) Stabilization of a clayey soil with fly ash and lime: a micro level investigation. Geotech Geol Eng 30(5):1197-1205

48. Chorom M, Rengaswamy P (1995) Dispersion and zeta potential of pure clays as related to net particle charge under varying $\mathrm{pH}$, electrolyte concentration and cation type. Eur J Soil Sci 46:657-665

49. Yukselen Y, Kaya A (2003) Zeta Potential of kaolinite in the presence of alkali, alkaline earth and hydrolyzable metal ions. Water Air Soil Pollut 145:155-168

50. Sposito G (1989) Surface reactions in natural aqueous colloidal systems. Schweiz Chem Verb 43:169-176

51. Kaya A, Yukselen Y (2005) Zeta potential of soils with surfactants and its relevance to electrokinetic remediation. J Hazard Mater B120:119-126

52. O'Flaherty CA (1988) Highway engineering-Volume 2, 3rd edn. Edward Arnold, London

53. Osula DOA (1991) Lime modification of problematic laterite. Eng Geol 30:141-154

54. Osinubi KJ, Ijimdiya TS, Nmadu I (2009) Lime stabilization of black cotton soil using bagasse ash as admixture. Adv Mater Res 62:3-10. doi:10.4028/www.scientific.net/AMR.62-64.3

55. Thomas GW, Sparks DL, Page AL, Helmke PA, Loeppert RH, Soltanpour PN, Sumner ME (1996) Soil pH and soil acidity. In: Methods of soil analysis, Part 3-chemical methods. American Society of Agronomy, Inc., Soil Science Society of America, Inc., Madison, pp 475-490

56. Silva JA, Uchida RS (2000) Plant nutrient management in Hawaii's soils: approaches for tropical and subtropical agriculture. College of Tropical Agriculture and Human Resources, University of Hawaii, Manoa, Honolulu

57. Kissel D, Isaac B, Hitchcock R, Sonon L, Vendrell P (2005) Lime requirement by measurement of the lime buffer capacity. http:// www.naptprogram.org/files/napt/publications/method-papers/ 2005-lime-requirement-by-the-measurment-of-the-lime-buffercapacity.pdf. Accessed 21 Aug 2012

58. Federer CA, Hornbeck JW (1985) The buffer capacity of forest soils in New England. Water Air Soil Pollut 26:163-173

59. Yong RN, Warkentin BP, Phadungchewit Y, Galvez R (1990) Buffer capacity and lead retention in some clay materials. Water Air Soil Pollut 53:53-67

60. Yong RN, Ouhadi VR, Goodarzi AR (2009) Effect of $\mathrm{Cu}^{++}$ions and buffering capacity on smectite microstructure and performance. J Geotech Geoenviron Eng 135:1981-1985

61. Magdoff FR, Barlett RJ (1985) Soil pH buffering revisited. Soil Sci Soc Am J 49(1):145-148

62. Weaver AR, Kissel DE, Chen F, West LT, Adkins W, Rickman D, Luvall JC (2004) Mapping soil $\mathrm{pH}$ buffering capacity of selected fields in the coastal plain. Soil Sci Soc Am J 68(2):662-668

63. Liu M, Kissel DE, Vendrell PF, Cabrera ML (2004) Soil lime requirement by direct titration with $\mathrm{Ca}(\mathrm{OH})_{2}$. Soil Sci Soc Am J 68(4):1228-1233 
64. Lierop WV (1983) Lime requirement determination of acid organic soils using buffer-pH methods. Can J Soil Sci 63(3):411-423

65. Lierop WV, Westerman RL (1990) Soil pH and lime requirement determination. In: Soil testing and plant analysis. Soil Science Society of America, Madison, pp 73-126

66. ASTM D4972-13 (2013) Standard test method for pH of soils. ASTM International, West Conshohocken

67. ASTM D2216-10 (2010) Standard test method for laboratory determination of water (moisture) content of soil and rock by mass. ASTM International, West Conshohocken

68. ASTM D4318-10e1 (2010) Standard test methods for liquid limit, plastic limit, and plasticity index of soils. ASTM International, West Conshohocken

69. ASTM D422-63 (2007) Standard test method for particle-size analysis of soils. ASTM International, West Conshohocken

70. IS: 1498 (1970) Classification and identification of soils general engineering purposes. Bureau of Indian Standards, New Delhi

71. ASTM D2487-11 (2011) Standard practice for classification of soils for engineering purposes (unified soil classification system). ASTM International, West Conshohocken

72. ASTM D698-12e (2012) Standard test method for laboratory compaction characteristics of soil using standard effort (12400 ft$\mathrm{lbf} / \mathrm{ft}^{3} \sim 600 \mathrm{kN} / \mathrm{m}^{3}$ ). ASTM International, West Conshohocken

73. Cerato AB, Lutenegger AJ (2002) Determination of surface area of fine-grained soils by the ethylene glycol monoethyl ether (EGME) method. Geotech Test J 25(3):1-7

74. Landon RE, Mogilnor AH (1933) Colusite, a new mineral of the sphalerite group. Am Mineral 18:528-533

75. Clark JS (1965) The extraction of exchangeable cations from soils. Can J Soil Sci 45:311-322

76. Greenwood R, Lapčíková B, Surỳnek M, Waters K, Lapčík L Jr (2007) The zeta potential of kaolin suspensions measured by electrophoresis and electroacoustics. Chem Pap 61(2):83-92
77. Alkan M, Demirbaş Ő, Doğan M (2005) Electrokinetic properties of kaolinite in mono- and multivalent electrolyte solutions. Microporous Mesoporous Mater 83:51-59

78. Keller WD (1963) The origin of high-alumina clay minerals-a review. In: Twelfth national conference on clays and clay minerals, pp 129-151

79. Evans P, Smith W, Vorobieff G (1998) Rethink of the design philosophy of lime stabilisation. In: Proceedings of the 19th ARRB conference, Sydney, New South Wales, Australia

80. Chan DH, Law T (2006) Soft soil engineering: Proceedings of the Fourth International Conference on soft soil engineering, Vancouver, Canada

81. Ogundipe OM (2013) An investigation into the use of lime-stabilized clay as subgrade material. Int $\mathrm{J}$ Sci Technol Res 2(10):82-86

82. Petry TMPE, Glazier EJ (2004) Project report: the effect of organic content on lime treatment of highly expansive clay. http://transportation.mst.edu/media/research/transportation/docu ments/092-cr.pdf. Accessed 21 Aug 2012

83. Sivapullaiah PV, Katageri B, Herkal RN (2007) Enhancement of strength of soft soils with fly ash and lime. In: 1st International conference on soil and rock engineering. Sri Lankan Geotechnical Society

84. Lasledj A, Al-Mukhtar M (2008) Effect of hydrated lime on the engineering behaviour and the microstructure of highly expansive clay. In: The 12th international conference of International Association for Computer Methods and Advances in Geomechanics, pp 3590-3598

85. Nasrizar AA, Muttharam M, Ilamparuthi K (2010) Role of lime content on soil-lime reaction under thermal curing. In: Proceedings of Indian geotechnical conference-2010, pp 595-598

86. Ramesh HNG, Sivapullaiah PV (2010) Role of moulding water content in lime stabilisation of soil. Ground Improv 164(1):15-19 